\title{
Corporate and State Responsibilities in Conflict-Affected Areas
}

\author{
Radu Mares* \\ Nordic Journal of International law, Volume 83, Number 3 (2014) pp. 293-345
}

\begin{abstract}
Some of the emblematic cases of corporate-related infringements of human rights have appeared in unstable and violence-ridden zones, including armed conflict and other contexts with lower levels of conflict, internal disturbances, widespread violence and latent tensions. Businesses have been involved in different ways, as direct perpetrators, accomplices or mere trading partners. This article tracks the issue of conflict-affected areas as elaborated in the United Nations (UN) Guiding Principles on Business and Human Rights during the Special Representative's mandate (2005-2011) and the post-mandate period of 2011-2014, especially by looking at the UN Working Group on business and human rights and the emerging National Action Plans. Conflict was a theme of high priority during John Ruggie's UN mandate but lost visibility in the post2011 period. What could explain this change? This article analyses in depth the relevant provisions in the UN Guiding Principles, particularly Principle 7, and how stakeholders have responded to the Special Representative's policy recommendations. The results of this analysis indicate that, contrary to appearances, Principle 7 is not merely an operational, context-specific principle limited to conflict-affected zones where the host state is incapacitated by conflict; rather Principle 7 should be seen as a foundational principle about gross abuses, about the responsibilities of home states to act preventively and reactively when 'their' companies are involved in gross abuses in conflict-affected areas and beyond.
\end{abstract}

\section{Contents}

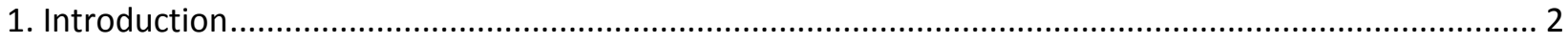

2. "Conflict-Affected Areas" in the UN Guiding Principles ..................................................................... 4

2.1 The Applicability of Principle 7 to Conflict Situations ….............................................................. 5

2.2 Corporate Responsibility to Respect Human Rights and 'Severity' of Impacts................................ 7

2.3 State Duty to Protect Human Rights and the Home State ............................................................. 10

2.3.1 Home State Responses to 'Adverse Impacts' Abroad ............................................................ 11

2.3.2 Home State Responses to 'Significant Risks' and 'Gross' Abuses .......................................... 12

2.4 Duties of Home States regarding 'Conflict-Affected Areas' ......................................................... 14

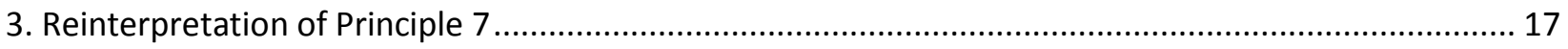

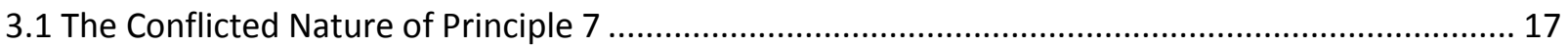

\footnotetext{
* Senior Researcher, Raoul Wallenberg Institute of Human Rights and Humanitarian Law, Associate Professor, Faculty of Law, Lund University, Sweden.radu.mares@rwi.lu.se
} 
3.2 Another Reading of Principle 7

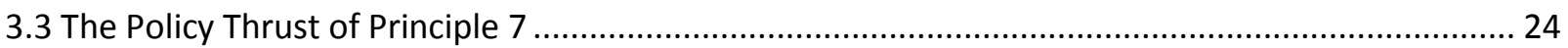

3.4 The International Law Debate: 'Precision Tool' versus 'Overarching Treaty' ................................... 26

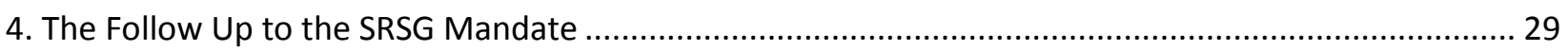

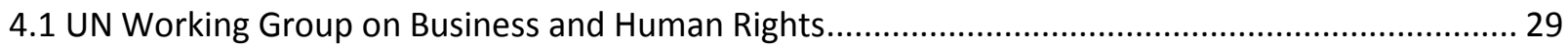

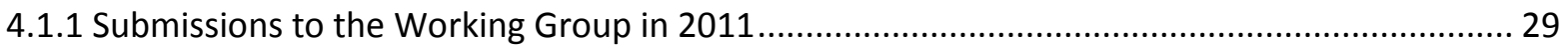

4.1.2 Surveys of States and Businesses by the Working Group in 2012 .......................................... 30

4.1.3 Feedback from the 2012 Multistakeholder Forum on Business and Human Rights................. 31

4.1.4 Reports of the UN Working Group (2012-2013) .................................................................. 32

4.1.5 Report of the Office of the High Commissioner (2012) ........................................................ 32

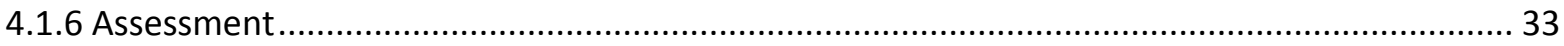

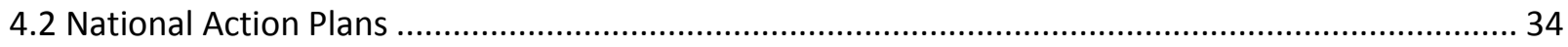

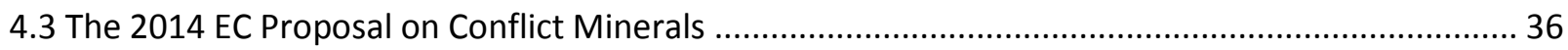

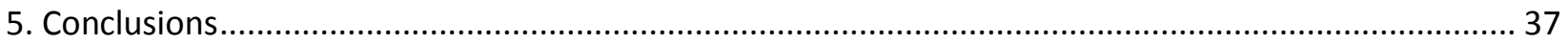

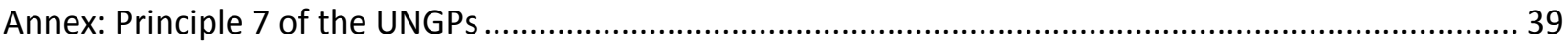

\section{Introduction}

Businesses activities take place in a variety of contexts, including armed conflict (international or national) and other contexts with lower levels of conflict, internal disturbances, widespread violence and latent tensions. It is thus not surprising that some of the emblematic cases of corporate unaccountability have appeared in unstable and violence-ridden zones: Talisman in a Sudan gripped by civil war; Shell in Nigeria during a military dictatorship which committed gross human rights violations, as well as other oil companies operating in a militarized Niger delta; and Freeport McMoRan mining activities in Indonesia's West Papua while an insurgency was taking place. Such well-known cases are however not limited to the extractive industry: Chiquita's banana operations in Columbia involved payments to paramilitary groups which were responsible for gross abuses during the civil war; the operations of private military companies in the war zones of Afghanistan and Iraq lead to concerns about 'privatized warfare'; ${ }^{1}$ the purchase of minerals from the conflict-torn countries of Angola, Sierra Leone and Democratic Republic of Congo called into question the responsibilities of companies using 'blood diamonds' and 'conflict minerals' in their products; the dealing of weapon-related materials brought the conviction of a Dutch businessman for selling chemicals to Saddam Hussein's regime which were used in the gassing and killing of thousands of Kurds in Iraq and Iran; and Caterpillar's supply of bulldozers to the Israeli military which were later used in house demolitions in the

\footnotetext{
${ }^{1}$ S. Percy, 'Regulating the private security industry: a story of regulating the last war', Humanitarian debate: Law, policy, action - Business, violence and conflict, 94:887 International Review of the Red Cross (Autumn 2012).
} 
Occupied Territories raised the responsibility of the company for how its products are used. ${ }^{2}$ Most of these cases have been brought before US courts applying the unique Alien Torts Statute to corporations involved in gross human rights violations occurring abroad. The conflict in the Congo lead to UN Security Council action and to ample documentation of the link between natural resources and conflict through the work of the Group of Experts (2004-); ${ }^{3}$ further regulatory action came most notably in the US through the Dodd-Frank Act's Section 1502 (2010).

Some of the earlier corporate social responsibility (CSR) initiatives have aimed to safeguard human rights in conflict-affected areas: the Kimberley Process (2000) aimed to stem the flow of 'blood diamonds' and the Voluntary Principles for Security and Human Rights (2000) were designed to protect local communities from abusive conduct of security forces guarding extractive industry facilities. The latest newcomer among the multistakeholder CSR initiatives is a Code dealing with military and security companies, the International Code of Conduct for Private Security Service Providers (ICoC) (2010). A great number of industry initiatives aim to ensure responsible sourcing of minerals by requiring the tracking of minerals throughout the supply chains and joint action of different participants in the chain; the Organisation for Economic Co-operation and Development (OECD) entered that debate with a range of guiding documents culminating with the Due Diligence Guidance for Responsible Supply Chains of Minerals from Conflict-Affected and High-Risk Area (2011). The development-retarding and conflict-inducing effects of the vast revenues that the extractive industries generate for unaccountable governments were the object of the Extractive Industry Transparency Initiative (2002).

As the above examples suggest, companies can be directly or remotely involved in human rights abuses, appear as the direct perpetrator, the accomplice or the beneficiary of abuse, be physically present in a conflict area or not. ${ }^{4}$ In all such situations, business operations are linked to human rights abuses, some of them reaching thresholds of egregious violations, such as genocide, slavery, summary executions, torture, enforced disappearances, arbitrary detention and other grave and systematic violations of human rights. ${ }^{5}$ The seriousness of the issues ensures that corporate responsibilities in conflict zones remain at the forefront of CSR discussions.

\footnotetext{
2 References to the cases mentioned above can be found on the Corporate Legal Accountability Portal of the Business \& Human Rights Resource Center, at <http://www.business-humanrights.org/LegalPortal/Home>.

${ }^{3}$ Reports of the Group of Experts Submitted Through the Security Council Committee Established Pursuant to Resolution 1533 (2004) Concerning the Democratic Republic of the Congo, $<$ http://www.un.org/sc/committees/1533/egroup.shtml>.

${ }^{4}$ Slim offers a comprehensive mapping and typology of the business-conflict interface by discussing six main roles of business in times of war. H. Slim, 'Business actors in armed conflict: towards a new humanitarian agenda', Humanitarian debate: Law, policy, action - Business, violence and conflict, 94:887 International Review of the Red Cross (Autumn 2012). Ganson and Wennmann describe business operations “around, in, or on fragile environments or conflict" and developed a "framework for conflict prevention in the context of large scale business investments in fragile environments" that draw on "the shared responsibilities but differentiated roles of business, government, and development actors”. B. Ganson and A. Wennmann, Confronting Risk, Mobilizing Action - A Framework for Conflict Prevention in the Context of Large-scale Business Investments (Friedrich-Ebert-Stiftung, 2012).

${ }^{5}$ Office of the High Commissioner for Human Rights, The Corporate Responsibility To Respect Human Rights - An Interpretive Guide, HR/PUB/12/02, 2012, p. 6 (hereinafter: Interpretive Guide).
} 
The UN Human Rights Council's unanimous endorsement of the Guiding Principles for Business and Human Rights (UNGPs) in 2011 marked the arrival of an authoritative, comprehensive and foundational treatment for the field of business and human rights. One of the principles is dedicated directly to "conflict-affected areas" (Principle 7). The article starts from the observation that during Special Representative of the Secretary General (SRSG) John Ruggie's mandate ${ }^{6}$ conflict areas occupied a high thematic priority that is not observable anymore in the post-UNGPs period. What could explain this change? How did the UNGPs conceptualize responsibilities in conflict-affected areas, and what policy recommendations did the SRSG put forward? How did stakeholders relate to these aspects in the wake of the UNGPs? The sources employed for the interpretative and comparative task carried out herein are the reports of the SRSG mandate and other writings of John Ruggie, the reports of the UN Working Group on business and human rights and a number of National Action Plans. The analytical focus herein is on the role of regulatory and governance responses outside of the host countries as a way to prevent and respond to corporate adverse impacts in conflict zones; in other words the discussion revolves around the transnational dimension revealing the responsibilities of multinational companies and home states. Against this thematic background there is an opportunity to reflect on corporate and state responsibilities - and the process of their legalization - when the discussion reaches the extremes of conflict zones and gross violations of human rights.

This article tracks the issue of conflict-affected zones as elaborated in the Guiding Principles by examining the SRSG mandate (2005-2011) ${ }^{7}$ and the post-UNGPs period of 2011-2014. The article has three sections: the first covers the SRSG mandate and describes the corporate and state responsibilities in conflict zones under the UNGPs. The second section undertakes an interpretation of Principle 7 which is designed to clarify its precise applicability through a textual and contextual analysis. The third section explores the post-UNGPs period by looking at the UNlevel work pursued by the Working Group and at home states' policies captured in National Action Plans (from the UK, Denmark, the Netherlands and the US - plans released until April 2014) implementing the UNGPs. This material assists in the interpretation of Principle 7 as it contains the stakeholders' responses to the treatment of conflict zones contained in the UNGPs; it also reveals continuity and discontinuity with the SRSG's conceptual approach to conflict zones in the work of the UN Working Group and home states.

\section{2. "Conflict-Affected Areas" in the UN Guiding Principles}

The first subsection discusses the notion of 'conflict-affected area' in an effort to discern the precise applicability of Principle 7. The next subsection turns to the corporate responsibilities to respect human rights and highlights some changes in expected business conduct when 'severe impacts' are at stake. Following that the state duty to protect human rights is presented with special emphasis on 'home' states' responsibilities.

\footnotetext{
${ }^{6}$ Resolution 2005/69 of the Commission on Human Rights 'Human rights and transnational corporations and other business enterprises'.

${ }^{7}$ Ibid.
} 


\subsection{The Applicability of Principle 7 to Conflict Situations}

The diversity of illustrations provided in the introduction may suggest a difficulty in defining 'conflict'. The terminology employed by the SRSG - 'conflicted-affected areas' - reflects the intention to expand the coverage of Principle 7 beyond definitions of armed conflict in international humanitarian law. The task of clarifying the applicability of Principle 7 also has to account for the more relaxed definitional boundaries that a soft law instrument like the UNGPs works with and the guidance-providing nature of Principle 7. So although utmost precision is not indispensable for grasping Principle 7, the question of what types of conflicts are left out of Principle 7 remains. For example, do localized conflicts triggered or aggravated by a mining company ${ }^{8}$ fall under Principle 7 or not?

It is notable that the theme of corporate activities in conflict-affected zones has occupied a prominent place, and proves to be a constant presence, in the SRSG's reports throughout his 2005-2011 mandate. In the resolution that started the SRSG mandate, the Commission on Human Rights did not refer expressly to conflict zones (it was not made a thematic priority), but the closest reference one could find was the request for the SRSG to research and clarify the implications for transnational corporations (TNCs) of concepts such as 'complicity' and 'sphere of influence'. ${ }^{9}$ Indeed, most instances of business involvement in gross abuses occurring in conflict zones do not see the company as the perpetrator, but rather as contributor in or beneficiary from the abuses committed by another public or private entity; both 'contributor' and 'beneficiary' scenarios have been covered under the label of 'complicity' in a stricter, legalistic sense or a non-legal, impressionistic sense. ${ }^{10}$ The six-year SRSG mandate was entrusted to Harvard University Professor John Ruggie. ${ }^{11}$ What began in the first report in 2006 with a single observation about the worst corporate-related abuses in countries characterized by 'current or recent conflict exposure' ended up in the 2011 Guiding Principles with a principle dedicated exclusively to "human rights in conflict-affected areas" (see the Annex for the full text of Principle 7) and an entire additional report about "Business and human rights in conflict-affected regions". ${ }^{12}$

Protecting human rights in conflict-affected zones has been a high thematic priority for the SRSG. Two reasons can be discerned for this special attention to conflict-affected zones. One has to do with the severity of abuse. As the SRSG wrote, "[t]he most egregious business-related

\footnotetext{
${ }^{8}$ A report of a controversial mine in Guatemala vividly explains localized conflicts. See section 7 on 'security' as well as the entire report substantiating the implications of conflict: "The number one stakeholder concern relates to the environment of conflict, tension, and fragmentation in the project-affected communities. The social and psychological effects of conflict are inseparable from the overall perceptions and impacts of the mine's human rights performance. While conflict has direct negative impacts on the right to security of the person and the right to health, it also has serious implications for all human rights discussed in the assessment. A vicious circle is created when conflict leads to human rights violations and infringements, which in turn lead to further conflict." On Common Ground Consultants Inc., Human Rights Assessment of Goldcorp’s Marlin Mine, 2010, p. 213.

${ }^{9}$ Resolution 2005/69, supra note 6, para. 1(c).

${ }^{10}$ For a critical evaluation of the use of complicity in CSR writings, see R. Mares, 'A gap in the corporate responsibility to respect human rights', 36:3 Monash University Law Review (2010).

${ }^{11}$ For Ruggie's own account of his years as Special Representative, see J. G. Ruggie, Just business: Multinational corporations and human rights (W.W. Norton \& Co, New York, NY, 2013).

12 Business and human rights in conflict-affected regions: challenges and options towards State responses, Companion report, A/HRC/17/32, 2011 (hereinafter: Conflict-affected regions report)
} 
human rights abuses take place in conflict affected areas and other situations of widespread violence. Human rights abuses may spark or intensify conflict, and conflict may in turn lead to further human rights abuses." ${ }^{13}$ Further, "gross human rights abuses, potentially amounting to the level of international crimes ... typically arise in areas where the human rights regime cannot be expected to function as intended, such as armed conflict or other situations of heightened risk". ${ }^{14}$

The other reason has to do with the ability of the state to protect rights. Thus the UNGPs write: "In conflict-affected areas, the 'host' State may be unable to protect human rights adequately due to a lack of effective control." 15 In his 2010 report, the SRSG indicated that "[t]he worst corporate-related human rights abuses occur amid armed conflict over the control of territory, resources or a government itself - where the human rights regime cannot be expected to function as intended and illicit enterprises flourish". ${ }^{16}$

There is however some uncertainty as to the relation between these 'gross abuses' and 'conflictaffected areas' that impact directly the applicability of Principle 7 to situations on the ground serious violations occurring in conflict zones that prompt home states into action to influence 'their' companies operating therein. Gross violations of human rights do occur in conflicts, but they also occur in the absence of a conflict, such as in repressive states and dictatorships. ${ }^{17}$ Should one consider that Principle 7 is inapplicable to such gross abuses? Furthermore, gross violations can occur in highly violent conflicts that are however localized and where it cannot be said that the state has lost control over its territory, such as in conflicts in the proximity of mining operations. Would Principle 7 be applicable or not to gross abuses taking place in such localized conflicts that do occur in 'democratic' 18 and authoritarian, oppressive states alike?

The reader is left in uncertainty, and three interpretations are conceivable: Principle 7 applies to a narrower category of conflicts where the host state loses control over part of the territory, or it applies more broadly to all types of conflicts including localized, low level conflicts, or it applies to gross abuses irrespective whether they take place in conflict areas or not. The host state would then be a 'failed state' or a state crippled by civil war that lost control over parts of its territory, or a functioning state - 'democratic' or not - that however does not fulfil its responsibilities in an area where large business projects fuel tensions and conflict, or a repressive state that inflicts gross abuses in the absence of a conflict. Companies operating in any of these three scenarios are at high risk of involvement in most severe abuses; therefore the imperative for home states to act regarding 'their' companies appears equally strong and is well operationalized through the measures recommended in Principle 7. To clarify the applicability of Principle 7, it is necessary

\footnotetext{
13 Ibid., Summary (italics added).

14 SRSG, Recommendations on Follow-Up to the Mandate, 11 February 2011 (italics added) (hereinafter: SRSG Recommendations)

${ }^{15}$ UNGPs Principle 7, Commentary (italics added).

${ }^{16}$ Business and Human Rights: Further steps toward the operationalization of the "protect, respect and remedy" framework, A/HRC/14/27, 2010, para. 44 (italics added) (hereinafter: Further steps)

${ }^{17}$ As the OHCHR noted, "the greatest risks [of involvement in gross human rights abuse] arise in conflict-affected areas, though they are not limited to such regions”. Interpretive Guide, supra note 5, p. 80.

${ }^{18}$ The term 'democratic' is used herein as “electoral democracy” in Freedom House's terminology. Freedom House explains that "the term "electoral democracy" differs from "liberal democracy" in that the latter also implies the presence of a substantial array of civil liberties.' Freedom in the World 2014 Methodology, http://www.freedomhouse.org/report/freedom-world-2014/methodology
} 
to understand better how conflict and gross abuses trigger home state action under the UNGPs and what kinds of measures are expected from home states under this Principle.

\subsection{Corporate Responsibility to Respect Human Rights and 'Severity' of Impacts}

The SRSG mandate clarified that businesses are under a 'responsibility to respect' human rights (RtR) which operationally requires 'human rights due diligence' understood as "the steps a company must take to become aware of, prevent and address adverse human rights impacts". ${ }^{19}$ In terms of how companies should deal responsibly with severe adverse impacts, including when operating in conflict-affected areas, Pillar 2 in the UNGPs is fully applicable. Two key dimensions of Pillar 2 are worth highlighting before clarifying what changes in terms of expected business conduct once a 'severe' impact, as opposed to a less severe one, is at play.

On the one hand, Pillar 2 clarifies the types of business involvement with the abuse. Thus Principle 13 explains that a company has a responsibility to respect when it causes, it contributes to or is directly linked through its business relationships to an abuse. In other words, the company can be the direct perpetrator, the accomplice or a business partner with the perpetrator. From the examples offered in the introduction, all three scenarios are readily identifiable: the private security providers (privatized warfare) commit themselves abuses and are perpetrators, the extractive companies assisting the security forces might be accomplices, and companies sourcing conflict minerals are linked to conflict through 'business relationships' for which the company is answerable. The RtR covers all of these situations where adverse impacts on human rights are the result of business activities.

On the other hand, Pillar 2 clarifies the expected action before, during and after adverse impacts occur. The RtR includes prevention and remediation. Human rights due diligence comprises the four main steps of: impact assessment, taking “appropriate action” to deal with the impacts, tracking performance, and communicating it publicly (Principle 17). These are systematic, proactive and reactive steps which are expected from a responsible, diligent company. Expected action in response to harm includes ceasing own harmful activities, ceasing own contributions or trading relationships with irresponsible (sub)contractors as well as exercising 'leverage' over affiliates infringing rights (Principle 19 Commentary). Remediation of impacts is called for when a company caused or contributed to harm, but not when a company merely had business relationships with the perpetrator (Principle 22).

The term 'severe' impacts appeared rather late in the SRSG's reports, for the first time in the 2011 UNGPs. The UNGPs refer in a number of places to abuses above a certain threshold through different terms such as severe impacts (Principle 14), gross abuses (Principles 7 and 23) and significant risk (Principles 4 and 16 Commentary). Out of the three, the term defined most precisely is that of 'severity'. Principle 14 explains severe impacts: "Severity of impacts will be judged by their scale, scope and irremediable character” (Commentary). These three factors were

19 Protect, Respect and Remedy: a Framework for Business and Human Rights, A/HRC/8/5, 2008, para. 56 (hereinafter: Protect, Respect and Remedy). Under the UNGPs, the RtR has three components: A policy commitment, a human rights due-diligence process, and remediation of adverse impacts (Principle 15). 
further clarified in the Interpretive Guide as referring to the "gravity [of impacts] and the number of individuals that are or will be affected (for instance, from the delayed effects of environmental harm)", and "irremediability" referring to the "ability to restore those affected to a situation at least the same as, or equivalent to, their situation before the adverse impact". ${ }^{20}$

Against this background, impacts understood as being 'severe' have a multitude of implications for the expected corporate response. Generally speaking an 'enhanced due diligence' process is warranted to deal with severe impacts. Furthermore, prioritization should be determined by severity. Thus Principle 24 allows and asks companies to "prioritize actions ... to prevent and mitigate those [impacts] that are most severe". Severity has, under the UNGPs, a host of other discrete implications for "formal reporting" (Principle 21), policy commitment "communicated actively" to the potentially affected stakeholders (Principle 16 Commentary), acting more quickly regarding third parties in "business relationships" (Principle 19 Commentary), treating such severe abuses as "a legal compliance issue” (Principle 23), and implementing more complex due diligence systems (Principle 14).

Such enhanced due diligence measures are all required because of severe impacts. Commenting on corporate involvement in gross human rights abuses and conflict-affected areas, the Interpretive Guide notes that:

Such contexts should automatically raise red flags within the enterprise and trigger human rights due diligence processes that are finely tuned and sensitive to this higher level of risk. Such heightened human rights due diligence should also be seen as essential if the enterprise has, or is considering entering into, business activities in countries that are under sanctions by the United Nations or regional intergovernmental organizations. ${ }^{21}$

When severe impacts occur in conflict affected zones, where the host state is dysfunctional and not protecting human rights, the situation of business involvement in severe abuses becomes even more alarming. It is notable that the SRSG did not simply broaden the RtR and ask companies to do more than respect human rights; the corporate responsibility does not expand to include 'protect' or 'fulfil' elements. 'Respect' only applies but its implementation has to display 'heightened' due diligence commensurate with the severity of impacts and higher risks because of operating in conflict-affected zones. As noted in a Shift report, “[c]ompanies' responsibility to respect human rights does not change when they work in these environments [current or latent conflict], and nor do the elements of human rights due diligence. However, respecting human rights usually requires greater attention, effort and resources at every step of the process.”22 Ruggie realized that broadening the RtR, even only exceptionally, would logically lead to the breaking point: companies becoming incentivized to stay out of conflict zones. ${ }^{23}$

\footnotetext{
${ }^{20}$ Interpretive Guide, supra note 5, p. 83.

${ }^{21}$ Interpretive Guide, supra note 5, p. 80 (italics added).

${ }^{22}$ IHRB and Shift, Oil and Gas Sector Guide on Implementing the UN Guiding Principles on Business and Human Rights, European Commission, 2013.

${ }^{23}$ This dynamic unfolded with the US Dodd Frank Act regarding the DRC even though the effort expected from companies did not appear prohibitive and even before the law entered into force. Companies sourcing minerals from DRC simply reoriented their purchase line towards regions other than DRC. This 'facile' legal compliance strategy unsettled NGOs and experts preoccupied with solving the DRC conflict. See section 4.3 below.
} 
A distinction should be made here regarding the types of business involvement in conflict. Dealing with a company that cannot conduct businesses without infringing rights (perpetrator) or with a company that 'knowingly contributes' to abuse (accomplice) is conceptually a straightforward issue; such a way of conducting business and such complicity are not justifiable under any conditions and an injunction is the only option conceivable. Dealing with the mere presence of companies in conflict zones or with companies trading with conflict zone actors is a more nuanced debate. Such a link to conflict zones is not complicity proper and cannot always simply be resolved with an injunction, as is the case with regard to 'conflict diamonds'. Indeed, companies - even by their mere presence - might play a positive role in conflict-affected areas before, during or after conflict. For this reason - to maximize the chance that corporate activity produces positive impacts on conflict dynamics without overburdening the RtR in Pillar 2 - the SRSG was keen to impress the imperative of heightened due diligence and emphasize the roles and responsibilities of states actors, particularly home states, to fill the void left by the host state (see section 2.3 below).

Acting on the information uncovered through due diligence can result in dramatic decisions of choosing to not conduct business in conflict zones. Indeed, under Principle 19 companies have to take "appropriate action" once impact assessment results are in, and a decision to not conduct business is one option. The SRSG explored the 'no-go concept' in a multistakeholder consultation in $2007 .{ }^{24} \mathrm{~A}$ full session was dedicated to a straightforward potential prescription for companies with activities in conflict zones. Should companies maybe not invest in or leave conflict zones? Would a prohibition to operate in such zone be a simple way of specifying the RtR and bring needed clarity ex ante? The consultation discussed the 'no-go concept' for those "circumstances so extreme that home States should advise companies against starting operations there, and advise those with existing operations to suspend them". The report notes that:

Participants suggested that "no-go" indicators could be taken from United Nations Chapter VII sanctions and international humanitarian law, but they indicated that other signals would also be required. It was emphasized that it may be difficult for a company to avoid complicity when operating in areas where massive human rights violations are committed. Thus, several participants argued that a "no-go" warning should always exist for areas where war crimes and crimes against humanity are taking place. ${ }^{25}$

Pillar 2 offers guidance on expected corporate conduct, but also draws attention to legal sanctions for severe adverse impacts. The SRSG emphasized the importance of current regulatory frameworks dealing with international crimes, at both international level and within national jurisdictions. Already in the 2006 report, the SRSG wrote: "Under customary international law, emerging practice and expert opinion increasingly do suggest that corporations may be held liable for committing, or for complicity in, the most heinous human rights violations amounting to international crimes, including genocide, slavery, human trafficking, forced labor, torture and some crimes against humanity."26 The SRSG was keen to bring to a company's attention that most severe impacts, often occurring in conflict zones, may generate legal liability as international standards and national laws increasingly interact and evolve to sanction gross

\footnotetext{
${ }^{24}$ Corporate responsibility under international law and issues in extraterritorial regulation: summary of legal workshops, Addendum 2 to the Report, A/HRC/4/35/Add.2, 2007, paras. 82-85.

${ }^{25}$ Ibid., para. 83.

${ }^{26}$ Interim Report of the Special Representative of the Secretary-General on the Issue of Human Rights and Transnational Corporations and Other Business Enterprises, E/CN.4/2006/97, 2006, para. 61.
} 
abuses. The UNGPs recommend to "[t]reat the risk of causing or contributing to gross human rights abuses as a legal compliance issue wherever they operate” (Principle $23 \mathrm{c}$ ). The Commentary explains with an eye on conflict affected areas:

Some operating environments, such as conflict-affected areas, may increase the risks of enterprises being complicit in gross human rights abuses committed by other actors (security forces, for example). Business enterprises should treat this risk as a legal compliance issue, given the expanding web of potential corporate legal liability arising from extraterritorial civil claims, and from the incorporation of the provisions of the Rome Statute of the International Criminal Court in jurisdictions that provide for corporate criminal responsibility. (Principle 23 Commentary, italics added)

In sum, the SRSG offered guidance and key reference points regarding expected corporate conduct in general, and for severe impacts in particular. The UNGPs impress on companies the importance of taking heightened due diligence measures and the tightening web of legal accountability. However, when it comes to conflict-affected zones, it is not in relation to corporate action that the SRSG mandate made the greater effort, but in relation to state action. Principle 7 deals with the responsibilities of home states for conflict-affected zones.

\subsection{State Duty to Protect Human Rights and the Home State}

The general stance of the SRSG on the issue of state obligations is to restate and elaborate the familiar trilogy of obligations under human rights law: states are obliged to respect-protect-fulfil human rights. Pillar 1 in the UNGPs deals with the state duty to protect the human rights impacted upon by business operations. Following international human rights law, the UNGPs provide that the host state has a duty to protect human rights; within its territorial jurisdiction the state has the legitimate power and legal obligation to set a regulatory and policy framework protective of human rights, and to ensure that judicial and non-judicial remedies are effective for victims of corporate abuse. Independent of the host state fulfilling its obligation to protect human rights, businesses have the responsibility to respect human rights by adopting due diligence measures and devising their own remedial mechanisms to effectively deal with rightholders' claims. Rightholders must have access to effective remedial mechanisms in order to ensure that those state obligations and corporate responsibilities are fulfilled.

This is the general treatment the 'Protect-Respect-Remedy' Framework applies to all types of adverse impacts generated by business operations. Two aspects related to Pillar 1 should be emphasized: the diverse capacities in which states act and can affect business operations, and the implications specifically for home states regarding human rights abroad.

Regarding the first aspect, one contribution of the SRSG consisted in offering a systematic account of the different capacities in which a state should act to protect rights. Thus Pillar 1 accounts for the state as a regulator (deploying an entire policy and regulatory toolkit), as an economic actor (through state-owned enterprises, financial support agencies, public procurement, in privatization processes) and a coherent actor (seeking policy coherence at different local, national and international levels). Principle 7 adds a role for the state as conflict-resolutor abroad, an exceptional thematic highlight applicable only to home states and neighbouring states to a host state affected by conflict. 
Regarding the second aspect, the UNGPs cover the responsibility of home states to act regarding businesses based in their jurisdiction but operating internationally and thus impacting human rights abroad. As a parenthesis, whether home states have extraterritorial obligations to protect human rights will not be focused on in this section; it suffices to say that Ruggie does not see extraterritoriality objections as an obstacle for some home state regulations and deems home states to have leeway ${ }^{27}$ to employ laws to shape 'their' companies' conduct with impacts abroad. ${ }^{28}$ Rather the interest herein is to determine how the SRSG reasons about the possibility and desirability for home states to use the law and to start an international law-making process leading to a treaty dealing with gross abuses in conflict situations. The following discussion is about the role of home states for impacts occurring abroad. To examine what the UNGPs expect from home states, the analysis is structured around three tiers: home state responses to adverse impacts, home state responses to 'significant risks' and 'gross' abuses, and home state responses to 'conflict-affected areas'. In this way one can easily track the changes in home state responsibility once adverse impacts advance towards thresholds of 'gross' abuses and the difficult context of conflict zones.

\subsubsection{Home State Responses to 'Adverse Impacts' Abroad}

Principle 2 is dedicated to how home states are expected to act regarding 'their' corporations with operations abroad: "States should set out clearly the expectation that all business enterprises domiciled in their territory and/or jurisdiction respect human rights throughout their operations." The Commentary writes about home states that "take steps to prevent abuse abroad by business enterprises within their jurisdiction", that "set out clearly the expectation that businesses respect human rights abroad", and that adopt "domestic measures with extraterritorial implications" (Principle 2 Commentary). Despite what the slightly euphemistic formulations might suggest, regulation by home states is never left out of the picture: "States should not assume that businesses invariably prefer, or benefit from, State inaction, and they should consider a smart mix of measures - national and international, mandatory and voluntary - to foster business respect for human rights” (Principle 2 Commentary).

Switching from the state as regulator to the state as economic actor, Pillar 1 forcefully makes another important point y: state-owned companies, public procurement bodies, export credit agencies and development agencies dealing with companies bring into question a state agency's own involvement in adverse impacts abroad. The UNGPs speak of the "state-business nexus", and the concept of human rights due diligence that is at the heart of Pillar 2 now becomes relevant to state agencies. Thus the Commentary to Principle 4 writes that "States should encourage and, where appropriate, require human rights due diligence by the agencies themselves and by those business enterprises or projects receiving their support” (italics added). Thus due diligence is a warranted prudential response expected from state agencies, which, like companies, are expected to diligently identify and address adverse impacts of their decisions. The due diligence steps are mutatis mutandis similar to those expected from companies in Pillar 2 to not

\footnotetext{
${ }^{27}$ Further steps, supra note 16, paras. 46-50. See also UNGPs, Principle 2 Commentary.

${ }^{28}$ A significant legal development occurred after the UNGPs were adopted. The US Supreme Court curtailed the extraterritorial reach of the Alien Torts Statute and ruled that ATS claims must "touch and concern the territory of the United States ... with sufficient force to displace the presumption against extraterritorial application”. Kiobel v. Royal Dutch Petroleum Co., 133 S.Ct. 1659 (2013).
} 
contribute or be linked to abuses in order to prevent, mitigate and remedy abuses (Principle 13). Indeed the state-owned enterprise is a company having the RtR just like any other company, according to Principle 14. For other state agencies, the UNGPs clarify:

A range of agencies linked formally or informally to the State may provide support and services to business activities. These include export credit agencies, official investment insurance or guarantee agencies, development agencies and development finance institutions. Where these agencies do not explicitly consider the actual and potential adverse impacts on human rights of beneficiary enterprises, they put themselves at risk - in reputational, financial, political and potentially legal terms - for supporting any such harm, and they may add to the human rights challenges faced by the recipient State. (Principle 4 Commentary, italics added)

What the aforementioned presentation indicates can be summarized as follows: home states are under a responsibility to act regarding 'their' companies abroad (inaction as the default position is not defensible), and the palette can extend from supportive policy to legally binding measures contained in law and contract (smart regulatory mix). What changes occur when severe abuses enter the picture?

\subsubsection{Home State Responses to 'Significant Risks' and 'Gross' Abuses}

The notion of "gross abuses" is only used in Principle 7 dealing with conflict-affected areas. Elsewhere in Pillar 1 the notion of "significant risk to human rights" is used several times to impress a heightened level of action from home states. The term 'severe impacts' is used nowhere in Pillar 1 to qualify state duties, but is a key concept used repeatedly in Pillar 2 to shape the corporate responsibility to act with due diligence. This abundance of terms raises the question of their relation to each other.

The relation between 'significant risk' and 'severe impact' is closer than it might appear at first glance. The Interpretive Guide explains that risks, understood as potential human rights adverse impacts, can be increased by either of two factors: the consequences of an event (its severity) and its probability. Therefore, significant risk does not automatically entail severity of potential harm; a high probability of occurrence suffices. However, the Guide further explains that "[i]n the context of human rights risk, severity is the predominant factor. Probability may be relevant in helping prioritize the order in which potential impacts are addressed in some circumstances ..."29 So 'significant risk' can to a large extent be equated with 'severe impacts', and both require from their addressees - states and companies respectively - a heightened level of action.

'Gross abuses', due to the understanding that they approach international crime thresholds or 'grave and systematic' character - are to be understood as one increment above the gravity of 'severe impact' and 'significant risk'. 'Gross' abuses is an interpretable term that international law already utilizes but does not define. ${ }^{30}$ Ruggie tried to clarify it by linking it to international

\footnotetext{
${ }^{29}$ Interpretive Guide, supra note 5, pp. 6-7.

30 The Basic Principles and Guidelines on the Right to a Remedy and Reparation for Victims of Gross Violations of International Human Rights Law and Serious Violations of International Humanitarian Law (General Assembly resolution 60/147 of 16 December 2005) do not define gross violations. See also the definitional problems and history in UN deliberations in J. Zerk, Corporate liability for gross human rights abuses - Towards a fairer and more effective system of domestic law remedies, A report prepared for the Office of the UN High Commissioner for Human Rights, 2014, pp. 25-29.
} 
crimes: "gross human rights abuses, potentially amounting to the level of international crimes" 31 . The Office of the High Commissioner for Human Rights (OHCHR) provided examples of gross abuses and further indicated that "economic, social and cultural rights can also count as gross violations if they are grave and systematic, for example violations taking place on a large scale or targeted at particular population groups". ${ }^{32}$

Employing any of the above terms translates in Pillar 1 into states being invited to employ regulatory measures. This happens in three discrete contexts. Principle 3, which covers the issue of corporate reporting of their human rights performance, states in relation to "significant risk": "A requirement to communicate can be particularly appropriate where the nature of business operations or operating contexts pose a significant risk to human rights" (Principle 3 Commentary).

In a similar fashion, Principle 4, which opens the discussion of the 'state-business nexus' and which covers state-owned enterprises and state agencies supporting businesses (export credit agencies and official investment insurance or guarantee agencies), begins by giving leeway to states to "encourage and, where appropriate, require” due diligence from both state agencies and companies linked to them. However regulatory and contractual measures are recommended where "significant risk to human rights" are present: "A requirement for human rights due diligence is most likely to be appropriate where the nature of business operations or operating contexts pose significant risk to human rights" (Principle 4 Commentary, italics added). It is unclear why this commendable clarification regarding the use of legal mechanisms is explicitly applied only to Principle 4 entities and not also to other facets of the state-business nexus (and Principle 6 regarding public procurement).

Principle 7 refers to gross abuses, which as mentioned above are one step above severe impacts in terms of the gravity of international crimes. Here home states are expected to employ legal means even more stringently. Thus, while Principle 4 asks home states to encourage or require human rights due diligence by the agencies themselves to deal with 'significant risks', Principle 7 asks home states to cut public support and services to businesses involved in gross abuses: "Denying access to public support and services for a business enterprise that is involved with gross human rights abuses and refuses to cooperate in addressing the situation”. Then, while Principle 2 asks home states to act by setting out clearly their expectation ("States should set out clearly the expectation that all business enterprises domiciled in their territory and/or jurisdiction respect human rights throughout their operations”), Principle 7 asks more forcefully for home states to hold such companies legally accountable: "Ensuring that their current policies, legislation, regulations and enforcement measures are effective in addressing the risk of business involvement in gross human rights abuses.” The Commentary further impresses the importance of legal accountability and speaks of "civil, administrative or criminal liability for enterprises domiciled or operating in their territory and/or jurisdiction that commit or contribute to gross human rights abuses. Moreover, States should consider multilateral approaches to prevent and address such acts, as well as support effective collective initiatives” (Principle 7 Commentary).

\footnotetext{
${ }^{31}$ SRSG Recommendations, supra note 14.

32 The examples offered by the OHCHR are "genocide, slavery and slavery-like practices, summary or arbitrary executions, torture, enforced disappearances, arbitrary and prolonged detention, and systematic discrimination". Interpretive Guide, supra note 5, p. 6.
} 
Thus both home states are expected to employ national and international law measures to deal with gross abuses.

In sum, the issue of severe abuses enters explicitly not in Principle 2 dealing with the generally applicable duties of home states but in the discrete contexts of Principles 3 (transparency), 4 (state ownership or support for companies) and 7 (conflict-affected areas). Outside of these three scenarios, home states are expected to employ the policy tool box as they deem fit.

\subsection{Duties of Home States regarding 'Conflict-Affected Areas'}

The theme of conflict situations has received special attention throughout the SRSG mandate. The 2008 Framework noted that "[t]he human rights regime cannot function as intended in the unique circumstances of sporadic or sustained violence, governance breakdown, and absence of the rule of law." 33 In his 2009 report, the SRSG wrote that "[t]he current international human rights regime cannot possibly be expected to function as intended where societies are torn apart by civil war or other major strife”. ${ }^{34}$ Back in 2006, the SRSG was writing more broadly that "weak governance poses a more general challenge to the established international human rights regime and requires special attention from all parties concerned”. ${ }^{35}$

As shown in section 2.2 above, the corporate responsibility remains about 'respect' only but is coupled with heightened levels of due diligence commensurate with the severity of impacts. Actually, the SRSG noted that there are already CSR initiatives guiding companies caught in conflict zones, but there is little clarity regarding what home states could and should do. So his mandate concentrated on clarifying the roles and responsibilities of home states when their businesses operate abroad in conflict-affected areas:

Several existing initiatives [by the UN, OECD, World Bank, International Committee of the Red Cross, Kimberley Process, the Voluntary Principles] address particular aspects of the role of business enterprises in zones of conflicts. ... Most of these initiatives primarily address the role of business enterprises. They provide useful guidance for responsible businesses, which increasingly seek ways to avoid contributing to human rights harm in these difficult contexts. But they do not provide much guidance for States, as a result of which there remains a lack of clarity with regard to what innovative, proactive and, above all, practical policies and tools States may have or should acquire for preventing or mitigating corporate-related abuses in situations of conflict. ${ }^{36}$

The SRSG began an ample process of consultation. He convened a multistakeholder event in 2007 together with the non-governmental organization (NGO) Global Witness which is dedicated to business operations in conflict zones. The 2010 report mentioned that that the SRSG "has convened a small, informal but representative group of States to brainstorm innovative ideas

\footnotetext{
33 Protect, Respect and Remedy, supra note 19, para. 47.

34 Business and human rights: Towards operationalizing the "protect, respect and remedy" framework, A/HRC/11/13, 2009, para. 43 (hereinafter: Towards operationalizing).

35 Interim Report of the Special Representative of the Secretary-General on the Issue of Human Rights and Transnational Corporations and Other Business Enterprises, E/CN.4/2006/97, 2006, para. 30.

${ }^{36}$ Conflict-affected regions report, supra note 12, paras. $7-8$.
} 
about how host, home and neighbouring States might help prevent or mitigate such abuses”. ${ }^{37}$ The group was involved in:

\begin{abstract}
informal, scenario-based, off-the-record brainstorming sessions to generate innovative and practical approaches for preventing and mitigating corporate abuses in these difficult contexts. On the agenda are the potential roles of home-country embassies; closer cooperation among home-State development assistance agencies, foreign and trade ministries and export finance institutions, as well as between them and host government agencies; and the possibility of developing early warning indicators for government agencies and companies. ${ }^{38}$
\end{abstract}

The result is that Principle 7, which is dedicated to conflict zones, is not placed by mistake in Pillar 1, which is dedicated to the state's duty to protect human rights. It puts the spotlight on the role of home states and neighbouring states. Furthermore, the SRSG framed the challenge as one of innovation, of policy innovations needed to deal with conflict in addition to what current international law - international human rights law with its reliance on host states, humanitarian law limited to armed conflict situations, and international criminal law limited to worst abuses defined as international crimes - has to offer. By the end of his mandate the SRSG delivered Principle 7, a companion 2011 report dedicated to conflict-affected zones, and a set of follow-up recommendations. It should be emphasized that the SRSG's approach is not a treatment of how to solve conflict but it is more narrowly about ensuring that businesses do not cause or aggravate conflicts. Principle 7 is about home and neighbouring states ensuring that the corporate RtR is fulfilled in conflict zones.

The companion 2011 report reflects a range of taxonomies the SRSG used to bring clarity on what can be expected from home states. ${ }^{39}$ First the options available to home states depend on the cooperative or uncooperative stance of the companies. Second, the organization of the workshops during consultations reflects the key distinction regarding corporate presence in conflict-affected zones and the corresponding options for states to engage with business enterprises: those companies that are physically present in zones of conflict and those businesses that are involved in foreign investment and trade activities that extend to conflict situations. Third, the options home states have point in three main directions: clarify the state's expectation from companies, provide information, and provide advice. Fourth, based on his principle of horizontal and vertical consistency, the SRSG stresses the key role of a home state's governmental bodies, like embassies in the field, and other state agencies linked to business operations through procurement, credits, guarantees and other forms of state support. Fifth, the SRSG's search for policy innovations steadily kept in the same picture three categories of states: home, host and neighbouring States.

Not only is the SRSG explicit of the wide palette of actions home states could and should take, but he also impressed the temporal dimension. More so than in any other area of rights abuses, conflict zones require proactive measures. Actually the UNGPs prompt home states not only into action, but into proactive action, and stress this fundamental point in diverse ways. The Principle 7 Commentary writes that "[i]t is important for all States to address issues early before situations on the ground deteriorate”. Principle 7 asks states to engage business enterprises "at the earliest

\footnotetext{
${ }^{37}$ Further steps, supra note 16, para. 12.

${ }^{38}$ Ibid., para. 45.

${ }^{39}$ Conflict-affected regions report, supra note 12.
} 
stage possible ... to help them identify, prevent and mitigate the human rights-related risks". The companion report writes that engagement "should start early, because prevention is cheaper than reaction for both States and business enterprises. It is furthermore more likely that engagement can be effective in helping business enterprises to avoid involvement in human rights abuse if it takes place before violence becomes widespread." 40 When exactly this proactivity kicks in is an unsettled issue though, and the SRSG concluded the companion report by asking states to work together, maybe through an international instrument, and define "what risks or activities should prompt a State response and what responses would be appropriate and necessary". ${ }^{41}$ Developing early warning indicators is one recommendation made in the Commentary as such indicators are key tools to enable effective responses from both states and companies. ${ }^{42}$

Principle 7 and the 2011 companion report both convey the recommendation for home states to employ regulatory measures. States are asked to provide "regulatory clarity" on (un)acceptable conduct, that is, to "clearly communicate their expectations with regard to business respect for human rights, even in such challenging environments... Normally, States would convey such expectations through policies, laws and regulations." 43 The role of law is unmistakably clear here: home states "should ensure that their regulatory frameworks are adequate, the applicability to business entities is clarified and, for the most extreme situation, make sure that the relevant agencies are properly resourced to address the problem of business involvement in international or transnational crimes, such as corruption, war crimes or crimes against humanity”. ${ }^{44}$

The SRSG refers to current and future international law mechanisms that are needed to effectively address conflict situations. As regards current international law mechanisms, the SRSG remarked on the role of the United Nations Security Council in dealing with conflict situations; his 2008 report noted that "[t]he use of Security Council sanctions targeting certain companies deemed to have contributed to conflicts in the Democratic Republic of the Congo, Sierra Leone and Liberia demonstrated a restraining effect. A recent report by the SecretaryGeneral recommends that this enforcement tool be continued and improved." 45 The SRSG further referred to the international criminal law system which can hold individuals, not corporate entities, accountable for involvement in international crimes. Also international humanitarian law is mentioned as this body of law creates obligations for private actors in armed conflict situations.

Regarding future international law, the SRSG left behind his reluctance to call for intergovernmental hard law solutions. ${ }^{46}$ The first indication appears in the Commentary to Principle 7 which invites states to "consider multilateral approaches to prevent and address such acts, as well

\footnotetext{
${ }^{40}$ Ibid., p. 4.

${ }^{41}$ Ibid., para. 20.

5, p. 80.

${ }^{43}$ Conflict-affected regions report, supra note 12, para. 12.

${ }^{44}$ Ibid., para. 13.

${ }^{45}$ Respect, Protect, Remedy, supra note 19, para. 48.

${ }^{46}$ See sections 3.3-3.4 below.
}

${ }^{42}$ Ibid., para. 15. Another SRSG report noted that “[t]here was also general consensus that a 'red flags' approach namely, a set of indicators signalling grounds for business and human rights concerns, which would also indicate the need for home State engagement - would be an important guiding tool”. Summary of five multi-stakeholder consultations, Addendum 1 to the Report, A/HRC/8/5/Add.1, 2008, p. 3. The Interpretive Guide also wrote: "Such contexts [conflict-affected areas] should automatically raise red flags within the enterprise and trigger human rights due diligence processes that are finely tuned and sensitive to this higher level of risk.” Interpretive Guide, supra note 
as support effective collective initiatives”. The idea is developed further in the 2011 companion report which notes that "[d]efining what risks or activities should prompt a State response and what responses would be appropriate and necessary" would be a necessary first step to operationalize Principle 7. It would be advisable to consider adopting an international legal instrument:

Such a standard setting exercise would be greatly supported by multilateral agreement on risks and prohibited activities with respect to business in conflict or other high-risk situations. States are more inclined to adopt policies that set standards that do not put their own businesses at an unfair disadvantage, indicating that multilateral standard-setting on this issue may be a necessary part of ensuring that States move forward in the fulfilment of the State duty to protect human rights. ${ }^{47}$

In his 2011 Recommendations to the UN Human Rights Council the SRSG developed the idea further. Therein the SRSG impresses the importance of "clarifying certain legal international standards" in the post-SRSG mandate period to deal with "gross human rights abuses, potentially amounting to the level of international crimes" that typically arise in "armed conflict or other situations of heightened risk". ${ }^{48}$ The SRSG outlined the key parameters of this international legal effort in:

an area where greater consistency in legal protection is highly desirable, and that it could best be advanced through a multilateral approach. Any such effort should help clarify standards relating to appropriate investigation, punishment and redress where business enterprises cause or contribute to such abuses, as well as what constitutes effective, proportionate and dissuasive sanctions. It could also address when the extension of jurisdiction abroad may be appropriate, and the acceptable bases for the exercise of such jurisdiction. It could also foster international cooperation, including in resolving jurisdictional disputes and providing for technical assistance. ${ }^{49}$

\section{Reinterpretation of Principle 7}

After processing the wealth of insights and recommendations contained in the SRSG's work, one might remain uncertain about the core thrust of Principle 7: is this Principle about conflictaffected zones or more broadly about gross abuses of human rights? In other words, does this Principle prompt home states into action whenever gross abuses take place or only where actual and potential conflict is present? The first subsection below highlights two points of disconnection in Principle 7, while the second subsection justifies a broad interpretation of Principle 7 as being about gross abuses. The last two subsections continue the interpretative task by looking deeper at the drafting choices behind Principle 7 in order to account in more detail for the policy thrust behind Principle 7: gross abuses demand an exceptional response from the international community and in the form of an international law instrument.

\subsection{The Conflicted Nature of Principle 7}

\footnotetext{
${ }^{47}$ Conflict-affected regions report, supra note 12, paras. 20-21.

${ }^{48}$ SRSG Recommendations, supra note 14.

49 To push this lawmaking process forward, the SRSG envisaged mechanisms such as an "expert mandate” or an “intergovernmental process of drafting a new international legal instrument". Ibid.
} 
The first tension in Principle 7 is between the title and the main text. Principle 5 refers to conflict in its title, but everything about the main text of Principle 7 is about gross abuses. Indeed the text of Principle 7 starts with 'gross abuses': "Because the risk of gross human rights abuses is heightened in conflict-affected areas ..." The guidance that Principle 7 offers to home states is equally applicable to gross abuses in all settings irrespective of the types of conflicts, or even in the absence of conflict altogether. The four provisions of the main text can be split in two groups. The first two provisions (a-b) couple the increased likelihood of occurrence (high-risk areas) with the grossness of abuse. The aim is to make it imperative for home states to act in two ways: act proactively and act supportively of well-meaning companies operating in difficult contexts (a-b). These are crucial points towards home states that otherwise would be content to not act at all (the 'no extraterritoriality' thinking) or only act repressively and post-facto (the 'accountability' thinking). However these high-risk of abuse zones are not necessarily conflictaffected areas; they can be in repressive, authoritarian regimes not affected by conflict and where the home state's proactive and supportive action is equally needed. The context is that of high 'risk of abuse', not narrowly of high 'risk of conflict'. ${ }^{50}$ The last two provisions (c-d) refer to gross abuses with no coupling to high probability of business involvement in such abuses. So even in this case the call towards the home states is not dependent on conflict, merely on the grossness of abuse. The point is to make it imperative for home states to act to separate themselves from gross abuse and to punish wrongdoers. In sum, the main text of the Principle 7 is conceptually dependent on 'gross abuses' and not on the conflict context.

The second tension is within the justificatory and operational parts in the Commentary to Principle 7. The Commentary explains the reasons behind this Principle and then offers more detailed guidance for home states. The first two paragraphs justify the existence of Principle 7 in a twofold manner. On the one hand, there is the incapacitated-by-conflict state unable to protect human rights due to loss of control over its territory. "In conflict-affected areas, the 'host' State may be unable to protect human rights adequately due to a lack of effective control” (paragraph 2) On the other hand, gross abuses occur in conflicts at the hands of both governmental and insurgent forces. "Some of the worst human rights abuses involving business occur amid conflict over the control of territory, resources or a Government itself - where the human rights regime cannot be expected to function as intended" (paragraph 1). Both of these justifications reflect the concern of the SRSG with the fundamental incapacity of the human rights law regime to function: ether human rights law does not apply in armed conflicts because it is humanitarian law that applies as lex specialis, or the host state is crippled by conflict and unable to protect rights.

Based on either of these two justifications, the call for action to home states is made. However this apparently leaves out gross abuses committed by the government when there is no conflict whatsoever (repressive, authoritarian regimes) as well as gross abuses in those lower level conflicts where the state is not incapacitated and is not 'authoritarian' (localized conflicts around mines and other large business projects in 'democratic' states). In neither of these two cases did

\footnotetext{
${ }^{50}$ A German non-governmental organization's report explains that Principle 7 covers areas "that are affected by warfare, armed conflict or recurrent violence which, although it remains below the threshold of what is defined as warfare, can rapidly escalate into a war or civil war. Time and time again, both State and private security forces are deployed in such areas to protect economic interests. Grave human rights violations, the militarisation of entire regions and the criminalisation of social protest movements and of human rights defenders are commonplace." Position Paper on Business and Human Rights - Expectations of a German Action Plan, CorA Network for Corporate Accountability and German Human Rights Forum, 2013.
} 
the host state lose control over its territory or become entangled in armed conflict. However a too close reading of the Commentary would leave them out of the scope of Principle 7. Disconnected from this justificatory part of the Commentary (paragraphs 1-2), the operational part of the Commentary (paragraphs 3-5) guides home states to act - to support business through information, advice, early-warning indicators, as well as to sanction through disengagement in the state-business nexus and criminal, civil, and administrative liability - and is geared towards (high risk of) 'gross abuses'. This operational part applies irrespective of the type of conflict highlighted in the justification part. Overall this operational part of the Commentary is geared toward 'gross' abuses, while the justificatory part that explains why home states should jump into action is geared toward 'conflict'.

It appears that Principle 7 exposes two disconnects: first, between the title (about conflictaffected zones) and main text (about gross abuses), and second in the Commentary between the justificatory part (why home states should act - because an incapacitated-by-conflict host state makes the human rights law regime ineffective) and the operational part (how home states should act). This creates confusion for those trying to understand the precise applicability and main thrust of Principle 7. There is the possibility that unless Principle 7 is properly interpreted gross abuses in repressive, authoritarian regimes and localized conflicts around mines in more 'democratic' regimes will fall outside the scope of Principle 7 for no good reason. Already some divergent interpretations appear in the literature that invokes Principle 7. Some see Principle 7 as applying narrowly to conflict contexts where the state lost effective control. ${ }^{51}$ Others deem Principle 7 to cover authoritarian regimes (so absence of conflict) or mainly some type of conflicts ('armed conflict'). ${ }^{52}$

The possibility exists that the real justification for home states' action has to do with the seriousness ('gross') of abuses in which 'their' companies might be involved abroad, and that Principle 7 is fundamentally about gross abuses that requires home state action.

\subsection{Another Reading of Principle 7}

The two disconnects above reveal how the drafting of Principle 7 entangles conflict and gross abuse. The blurred focus of the principle creates difficulties in communicating persuasively with stakeholders and opens the applicability of the Principle to divergent interpretations. The interpretation proposed herein would give priority to the operational part containing guidance to home states to the detriment of the title and justification offered in the Commentary. Such an interpretation is warranted for a number of reasons.

\footnotetext{
${ }^{51}$ Kyriakakis acknowledged that "[w] hile the Guiding Principles refer only to the inability of the host state to protect human rights in conflict contexts due to a lack of effective control, international criminal law teaches us that another factor often at play is an unwillingness on the part of host states to protect against international crimes due to the state's own involvement in such crimes”. J. Kyriakakis, 'Developments in international criminal law and the case of business involvement in international crimes', Humanitarian debate: Law, policy, action - Business, violence and conflict, 94:887 International Review of the Red Cross (Autumn 2012) (italics added).

${ }^{52}$ An ICAR report construed Principle 7 in an overtly narrow and extensive fashion simultaneously. On the one hand, it considered a priority for future state action to deal with the "violent conflict abroad" where companies are "caught up in war and dictatorship". On to other hand, it understands Principle 7 to be about "zones of armed conflict" and "a particular context of violent conflict". M. B. Taylor, Human Rights Due Diligence: The Role of States, Progress Report, ICAR, 2013 (italics added).
} 
First, 'conflict-affected area' is an inherently broad notion. Its precise boundaries become more elusive the more one tries to pinpoint them. This is due to at least two reasons. By design this notion is meant to cover lower levels of conflict that go beyond 'armed conflict' as used in humanitarian law. What that low threshold of violence would be is impossible to state with precision. Then the notion of 'conflict-affected area' also encompasses pre- and post-conflict stages; the temporal dimension is at the core of this notion as actors are asked to take action to prevent an escalation, or relapsing back, into acute conflict.

Second, the character of the UNGPs is that of a soft law instrument and Principle 7 is about 'guidance' even more than the rest of the UNGPs. ${ }^{53}$ The UNGPs do not attempt to define 'conflict-affected area', nor should they, because the instrument is not about imposing legal liability which would have indeed required much higher levels of clarity on key concepts. Therefore the debate in humanitarian law regarding the start of an armed conflict is important as it determines the applicability of that body of law to the conflictual situation at hand. That 'soft law' nature of the UNGPs in itself carries not only a dose of imprecision that would not be acceptable in a hard law instrument, but also prevents one from interpreting such soft law too narrowly unless clear reasons justify it.

Third, 'gross abuses' of human rights are often considered an indicator of impending conflict. The relation between 'gross abuses' and 'conflict-affected areas' grows more direct once the policy imperative of prevention is accounted for. The two notions become more difficult to separate and indeed documents from the UN Global Compact ${ }^{54}$ and the OECD ${ }^{55}$ find it necessary to use the umbrella phrase of "conflict-affected and high-risk areas". From this angle there is less purpose in a document like the UNGPs to seek clarity by drawing strong dividing lines between the two notions and ignoring their interrelatedness. Clarity on the applicability of Principle 7 needs to be obtained in a different way.

Fourth, Ruggie himself explored the loose boundaries of 'conflict-affected areas' by also invoking the 'high risk' expander used by the OECD and Global Compact. The 2011 Report

\footnotetext{
${ }^{53}$ CSR instruments "do not provide much guidance for States, as a result of which there remains a lack of clarity with regard to what innovative, proactive and, above all, practical policies and tools States may have or should acquire for preventing or mitigating corporate-related abuses in situations of conflict”. Conflict-affected regions report, supra note 12, paras. 7-8.

${ }^{54}$ The Global Compact, which has launched in 2013 the 'Business for Peace' platform, writes that there is no single definition of a 'conflict-affected' or 'high-risk' area, but these "terms include regions where there is political or social instability, violent conflict or abuses of political and civil liberties". Global Compact, Responsible Business Advancing Peace: Examples from Companies, Investors \& Global Compact Local Networks, 2013. Elsewhere the Global Compact indicated that the terms 'conflict-affected or high-risk area' refer to "a wide range of areas, including those experiencing: violent conflict including war or insurrection; elevated political \& social risk or instability; concerns about human rights abuses; or a transition out of conflict”. Global Compact, Business For Peace: A Business Leadership Platform, 2013.

${ }^{55}$ In its Guidance on sourcing minerals, the OECD defines 'conflict-affected and high-risk areas' in relation to "the presence of armed conflict, widespread violence or other risks of harm to people”. By 'armed conflict', the OECD covers conflicts of international or non-international character, including "wars of liberation, or insurgencies, civil wars, etc.”. By 'high-risk areas' the OECD refers to "areas of political instability or repression, institutional weakness, insecurity, collapse of civil infrastructure and widespread violence. Such areas are often characterised by widespread human rights abuses and violations of national or international law.” OECD Due Diligence Guidance for Responsible Supply Chains of Minerals from Conflict-Affected and High-Risk Areas, Second edition, 2013.
} 
speaks of "conflict or other high-risk situations"; the 2011 Recommendations referred to gross human rights abuses that typically arise in "armed conflict or other situations of heightened risk". ${ }^{6}$ Elsewhere the SRSG voiced his concern about "situations of widespread violence",57 about "societies [that] are torn apart by civil war or other major strife". ${ }^{8}$ These and other formulations quoted throughout this article do indicate that the SRSG's concern expands beyond conflict narrowly defined into zones of high risk for severe human rights infringements.

Fifth, the documents from the UN Working Group and some National Action Plans (section 4 below) routinely refer to unrest and abuses around mines as 'conflict'; also home states seem inclined to act with priority against the most serious abuses abroad irrespective of conflict. It is precisely such localized conflicts and gross abuses in the absence of conflict that are in danger of not being covered by a narrow interpretation of Principle 7. Clearly the concern in these documents is with the most serious abuses - no matter the setting they occur in as these can take place equally well inside conflicts as well as outside conflict - and the absence of effective remedies available to victims.

Sixth, the more recent statements from Ruggie regarding the desirability of new hard law instruments explicitly covered 'gross abuses' and 'conflict zones' separately. Given that nowhere outside Principle 7 did the SRSG call for international law measures to deal with gross abuses, Ruggie's statements indicate that Principle 7 - with its unique (in the UNGPs) policy thrust calling for national and international law measures involving home states - should be interpreted to cover all types of conflict and gross abuses irrespective of conflict. The former SRSG was present at the launching of the UK National Action Plan where he underlined:

Exceptional legal measures may be needed where the human rights regime cannot possibly be expected to function as intended, as for example in conflict zones; and where it concerns business involvement in the worst human rights abuses. The international community no longer regards sovereignty as a legitimate shield behind which egregious human rights violations can take place with impunity; surely the same must be true of the corporate form. Greater clarity on this critical point would benefit all stakeholders. ${ }^{59}$

Seventh, consistency between Pillars 1 and 2 advises for Principle 7 to cover 'gross abuses' in all circumstances, irrespective of conflict. Indeed Pillar 2 emphasizes 'severity' of impacts and requires companies to undertake heightened due diligence; companies should address with priority severe impacts. In a similar fashion, 'gross' abuses should require enhanced action from home states; Principle 7 rightly asks home states to act preventively and with the full force of law: legal measures against 'their' non-compliant companies and an international legal instrument to solve collective action problems inhibiting home states from acting.

Finally, in light of the previous considerations, the danger carried by a narrow interpretation is of arbitrarily restricting the applicability of Principle 7 . That would be a peculiar choice given the emphasis placed on an essential issue such as 'gross abuses'. Unless good reasons exist, like for example 'extraterritoriality' objections of host states against a home state for overstepping its

\footnotetext{
${ }^{56}$ Conflict-affected regions report, supra note 12, para. 21; SRSG Recommendations, supra note 14.

${ }^{57}$ Conflict-affected regions report, Summary, supra note 12.

${ }^{58}$ Towards operationalizing, supra note 34, para. 43.

${ }^{59}$ J. G. Ruggie, Remarks at UK Government Launch Action Plan for Implementing the UN Guiding Principles, Institute of Directors, London, 4 September 2013, (italics added).
} 
jurisdiction, the UNGPs should not be plagued by charges of arbitrariness on such a serious issue. But even regarding extraterritoriality, the measures proposed in Principle 7 do not appear problematic: some measures are directed at a home state's own agencies only, all measures taken by the home state target 'their' companies (domiciled in the home state but operating abroad), and all measures tackle the most serious infringements of human rights (significant agreement exists internationally on the issue of gross abuses).

The justification behind Principle 7, articulated in the Commentary, is to compensate for the host state incapacitated by conflict and who lost control over some of its territory, and for those acute conflicts where rules are disrespected by all parties; because corporate impunity results from the human rights regime not being able to function, home states cannot remain passive but have to act regarding 'their' companies operating in such contexts. However the imperative for home states to act in the face of high risks of gross abuses necessarily breaks the confines of the initial justification. Indeed there are related settings where the human rights regime cannot function effectively: unstable areas that are heading towards conflict or struggling to recover from conflict. Home state action is equally needed in such pre- or post- conflict settings. Going further, given that the measures outlined in Principle 7 were carefully tailored to resist extraterritoriality challenges, it soon becomes unjustifiable to tackle gross abuses in the aforementioned settings and turn a blind eye to corporate involvement in other settings, like authoritarian regimes where gross abuses are present. Such repressive regimes are not considered stable with gross abuses being an indicator of their longer term instability and potential for descending into conflict. It would be arbitrary if the measures in Principle 7 did not apply and corporations would not similarly benefit from state support and be subject to sanctions when being involved with gross abuses in such repressive environments. Thus, the carefully tailored policy measures contained in Principle 7 when combined with the irreducibly broad notion of 'conflict-affected zone' encourage a reinterpretation of Principle 7.

The analysis herein concludes that the centre of gravity in Principle 7 is 'gross abuses' while 'conflict-affected areas' is one setting only, used for powerful exemplification. One would be ill advised to seek the clarification of Principle 7 by working the 'conflict zone' element. 'Conflictaffected area' is a notion used by design in an encompassing way: actual and potential conflicts, pre- and post-conflict stages are covered, forms of violence extending beyond armed conflict are also included, while gross violations can be a symptom of a looming conflict as well as a byproduct of conflicts. Mining, other infrastructure projects and large agri-business projects are often controversial ${ }^{60}$ and spark disputes and conflict. ${ }^{61}$ Seeking to draw precise boundaries for

\footnotetext{
${ }^{60}$ Ganson and Wennmann explain the imperative for action in the case of localized conflict from an even broader perspective than the UNGPs. "Business investments often create stresses at the community level and also present conflict triggers for broader political, economic, social, and ecological systems. ... The current intensification of mining activities, commercialisation of significant land areas, and undertaking of large infrastructure projects in fragile environments is leading to increased and often violent conflict at the local level. With development, peacebuilding and investment agendas at risk, there is a clear imperative for action." Ganson and Wennmann, supra note 4, (italics added)

${ }^{61}$ Ruggie wrote that "[t]his is not necessarily 'conflict' in the sense of people shooting at each other. It includes lower levels of conflict" and examined the costs of such conflicts: "What does it actually cost companies in terms of pipelines being blown up, access roads to mines being shut down, facilities attacked, company personnel kidnapped, or simply consuming the time and energy or staff, and so on?” V. Bernard, 'Interview with John G. Ruggie', Humanitarian debate: Law, policy, action - Business, violence and conflict, 94:887 International Review of the Red Cross (Autumn 2012).
} 
'conflict-affected zones' in Principle 7 is a challenging endeavour, and one recalls that even defining 'armed conflicts' for purposes of applying humanitarian law is not a straightforward issue. $^{62}$ Such an attempt would only introduce arbitrary distinctions that run against Principle 7's core function to offer operational guidance to home states and Principle's 7 core recommendation for international law measures to be taken for extreme abuses.

Contrary to its title, Principle 7 is about (high risk of) gross abuses requiring exceptional actions from home states, and not narrowly about conflict-affected areas. Furthermore the conflict settings alluded to in the Commentary are merely examples where the call to action issued by Principle 7 should be followed; not only should 'conflict' in Principle 7 be interpreted broadly (to include localized conflicts and tensions generated by large business projects) but it should be recognized that the Principle applies even to non-conflict settings if gross abuses take place (to include repressive, authoritarian regimes). Forceful home state action should follow 'gross abuses' in all these settings. The title of Principle 7 could have benefited from the usual encompassing phrase - 'conflict-affected and high-risk areas' - used by the OECD and Global Compact to draw attention to most serious abuses in weakly governed and repressive states.

The nature of Principle 7 is different from what might appear at first glance. Because it is about gross abuses rather than simply conflict-affected zones, Principle 7 is not that context-specific. It is less of an operational principle and more of a foundational one. Actually Principle 7 is weak in original content: it tends to repeats points made already in other contexts: policy coherence (Principle 8), no support for rights-infringing companies (Principle 4 on the "state-business nexus"), home state to act through a regulatory mix (Principle 3). Even the exceptional call for international law action reflects the recommendation to cooperate through multilateral settings (Principle 10). What distinguishes Principle 7 is that the SRSG was more prescriptive and emphasized the role of hard law more than in any of the other principles mentioned above. That reflects a heightened level of action expected from home states that reflects the increased severity of abuses (gross abuses); this parallels the reasoning in Pillar 2 where companies are expected to deploy heightened due diligence where 'severe' impacts are detected. What Principle 7 does is compile types of action expected from home states as described in other principles of Pillar 1, and raises the stringency of demands a notch. The affinity of Principle 7 is not with the rest of the operational principles in Pillar 1 (3-10), but with foundational Principle 2 dealing with the responsibilities of home states.

The interpretation herein informs both the cursory and attentive readers of the UNGPs. Is this analysis not taking too long of a detour to come to the obvious point that Principle 7 should be interpreted broadly because it speaks of 'conflict-affected areas', and not of 'conflict' or 'armed conflict'? The reader having only a cursory look at the UNGPs and reading the title of Principle 7 is inclined to cover all types of conflicts, including localized tensions and violence around mines. A lingering thought might be whether it is reasonable to ask the home state to act regarding lower level conflicts abroad (e.g. localized tensions around a mine), and whether there might be some extraterritorial objections from host states. Seeking an answer, that reader looks more closely at

\footnotetext{
${ }^{62}$ E. Wilmshurst (ed.), International Law and the Classification of Conflicts (Oxford University Press, 2012). See also the book review by Roberta Arnold noting that "the classification of (armed) conflicts [is] one of the most complex contemporary issues of the laws of war" , in Humanitarian debate: Law, policy, action - Business, violence and conflict, 94:887 International Review of the Red Cross (Autumn 2012).
} 
the text and Commentary accompanying Principle 7, and might become uncertain. The more curious reader will have already plunged into the details of Principle 7, seeking to discern the precise justification and applicability of the Principle given the diversity of conflicts. This reader might be left with the impression that Principle 7 is about conflicts where the state lost control over its territory. Or s/he will notice the broader concern of the SRSG with situations where rule of law does not operate because the human rights regime is not functioning effectively where conflicts are raging. This reader will think of the two scenarios that do not fit these conditions conflicts around large business projects in 'democratic' states (the human rights regime is not derailed) and gross abuses where there is no conflict (repressive, authoritarian states engaged in gross abuses) - and whether Principle 7 covers them. That closer look at the Commentary also notes the well-balanced measures recommended to home states that do not seem to raise extraterritorial concerns and to the strong emphasis on 'gross' abuses; the question is then whether Principle 7 might arbitrarily exclude the two scenarios.

For both the cursory and attentive reader, the interpretation herein offers insight: the cursory reader understands that Principle 7 is, despite its title, not only about conflict situations but also about non-conflict settings if gross abuses take place (authoritarian states). The attentive reader is informed to not interpret Principle 7 narrowly and screen out some types of conflicts; further, to not seek clarity on the applicability of Principle 7 by working the 'conflict' element but instead to account more strongly for the 'gross abuse' element; and finally to remark that Principle 7 is exceptional as the only principle in the UNGPs that asks home states to act forcefully (through international and national law) where most serious abuses abroad involve 'their' companies.

\subsection{The Policy Thrust of Principle 7}

So far the analysis clarified the main conceptual thrust and applicability of Principle 7. Criticism was raised with regard to the drafting of the principle but this should not detract from the key message contained in Principle 7: gross abuses demand an exceptional response from the international community and in the form of an international law instrument. Principle 7 carries a policy recommendation of high importance for the evolution and legalization of the business and human rights regime. It is therefore important for the analysis and criticism of Principle 7 not to stop before the policy thrust of the SRSG work is outlined in more detail.

It is true that 'gross abuses' and 'conflict-affected zones' carrying an increased probability of abuses are not equivalent spheres. Arguably what the SRSG aimed for was the area of overlap to give a maximum normative boost to his call for home states to act through national and international law. By amalgamating the issues of 'gross abuses' and 'conflict zones', Principle 7 taps two separate normative sources able to fuel a call for home states to act through national and international law.

With regard to gross abuses, which the SRSG defines as infringements so serious that they approach the level of international crimes, Ruggie draws on the significant developments in international criminal law. The establishment of the International Criminal Court (ICC) was a watershed moment in international law and a response to the worst human rights abuses. Although the ICC does not have jurisdiction over companies or other artificial persons, Ruggie drew attention to the "expanding web of potential corporate legal liability" (Principle 24) where 
international crimes are enforced through national legal systems. Arguably the SRSG took notice of a legal field in flux and the trend towards business accountability in which the issue of gross abuses could be anchored. Furthermore, a new legal instrument would cover companies and possibly enlarge the currently limited categories of international crimes to include other most severe abuses.

With regard to conflict-affected zones, Principle 7 puts the spotlight on the host state's incapacity to discharge its duty to protect. Given that the host state is the foundational stone of the human rights law regime, the thrust of Ruggie's argument is in exceptionally compensating for the fundamental derailment of that regime when conflict incapacitates the host state or brings the worst out of all parties to the conflict. With the human rights regime not functioning, the SRSG appeared concerned that there are devastating impacts from violence that might not be appropriately covered by the rules of humanitarian law (limited to armed conflict) and international criminal law (limited to a narrow list of crimes), not to mention judicial enforcement difficulties that these bodies of law encounter. To narrow this gap, Principle 7 proposed an exceptional responsibility to act of home states and a new international legal instrument. The latter would also address any perceived or genuine concerns about extraterritorial action and alleviate collective action problems inhibiting home states to act regarding 'their' companies operating abroad.

The SRSG appears to seek a reinforced justification behind the proposed responsibility to act of home states. Although gross abuses and conflict zones are not coextensive and draw on separate rationalities - the "expanding web" of accountability for international crimes (gross abuses) and the systemic gap in international human rights law when the host state is incapacitated (conflictaffected zones) - to prompt states into international action, the two areas clearly overlap to a significant extent. Principle 7 seems to target that area of overlap to maximize the normative force of its message. Arguably referring to both of them in one breath reinforces the urgency of the call to action. To illustrate, the SRSG was uniquely candid in his writings and prompted home states into action:

... the scale of the current impasse must and can be reduced. To take the most pressing case, what message do States wish to send victims of corporate-related abuse in conflict affected areas? Sorry? Work it out yourselves? Or that States will make greater efforts to ensure that companies based in, or conducting transactions through, their jurisdictions do not commit or contribute to such abuses, and to help remedy them when they do occur? Surely the latter is preferable. ${ }^{63}$

The SRSG's assessment of the inadequacy of home states' responses to date was informed by a multistakeholder consultation. The report of that meeting notes that:

Participants in the consultation concluded that home States should play a bigger role in addressing business and human rights concerns in conflict areas. There was general consensus that home State policies and practices in relation to this challenge, where they existed at all, were limited, fragmented, mostly unilateral and ad hoc. Many home States also appeared to lag behind both international lending institutions and responsible businesses in grappling with these difficult issues. Furthermore, many if not most home States were found to appear to assign considerably greater weight to promoting exports and foreign investments than to human rights concerns. ${ }^{64}$

\footnotetext{
${ }^{63}$ Further steps, supra note 16, para. 47

${ }^{64}$ Summary of five multi-stakeholder consultations, supra note 42, p. 3.
} 
In the UNGPs, and most strongly in his 2011 Recommendations, the SRSG asked for a new international legal instrument while still adding: “All these measures are in addition to States' obligations under international humanitarian law in situations of armed conflict, and under international criminal law" (Principle 7). The policy thrust behind Principle 7 is to achieve a triad of international humanitarian law, international criminal law and a Principle 7-based treaty to deal with gross abuses (a threshold lower than international crimes) and in conflicted-affected zones (not covered by humanitarian law limited to armed conflict) by mobilizing home states to act with extraterritorial effects (laws and remedies beyond what international human rights law currently offers). The SRSG envisioned a triad of international law responses to gross human rights violations.

The SRSG seems to have attempted with Principle 7 a sensitizing move by highlighting corporate involvement in gross abuses in a special, most dramatic context: in conflict-affected zones, where an incapacitated state lost control over parts of its territory or where conflict is raging with total disregard for human rights, home states should act. ${ }^{65}$ The importance of a proper understanding of Principle 7 does not lie solely in its applicability to factual situations on the ground (UNGPs are not hard law). Rather the interpretation conducted herein also tries to account for how the drafting of Principle 7 seeks to gain maximum normative force to get home states to act by tapping into two separate sources of authority: recent developments in international criminal law regarding gross abuses and the structural gap in a human rights regime relying on the host state now incapacitated or entangled in conflict. ${ }^{66}$

Principle 7 is remarkable from another angle as well: it contains a call for an international treaty from a SRSG criticized for not going the 'treaty road' during his mandate. The next section will track how Ruggie's call was received and the clash of views on how to use international law international law as 'precision tool' versus 'overarching treaty' - to best push the business and human rights field forward.

\subsection{The International Law Debate: 'Precision Tool’ versus 'Overarching Treaty'}

The SRSG's call for an international legal instrument dedicated to conflict-affected areas and gross abuses has not been followed. ${ }^{67}$ A 2013 report of the European Parliament recalls the

\footnotetext{
65 Ruggie stated: "It is my belief that conflict situations warrant special measures on the part of governments, both host and home governments - the latter especially where the host governments may not be in control of a particular part of a country in which a conflict is taking place. ... A greater role is imposed on home and on neighbouring countries to ensure that conflict zones do not end up being law-free zones... Also, I think this is an area in which further international legal measures are warranted, because, as I noted earlier, the human rights regime cannot possibly function as intended in a situation of extreme duress or outright conflict.” Bernard, supra note 61.

${ }^{66}$ Furthermore, in tune with the participatory approach characterizing his six-year mandate, the SRSG also invoked the widespread stakeholder consensus: “The SRSG's consultations with all stakeholder groups have indicated a broad recognition that this is an area where greater consistency in legal protection is highly desirable, and that it could best be advanced through a multilateral approach.” SRSG Recommendations, supra note 14.

${ }^{67}$ A former SRSG team member noted: "This recommendation was not taken up by the UN Human Rights Council, however, and it remains an outstanding gap in the international framework for the prevention and redress of gross human rights abuses.” R. Davis, 'The UN Guiding Principles on Business and Human Rights and conflict affected
} 
SRSG's address made in 2009 at a European Union (EU) meeting. The SRSG appealed then to the EU states "to clarify and support the issue of extraterritorial jurisdiction for violations by companies in fragile third countries [and that] his appeal was subsequently endorsed in European Council conclusions, but no action has been taken in response to it to date". ${ }^{68}$

Ruggie's treatment was geared towards urgently obtaining special measures for gross abuses and conflict-affected zones: the responsibility of home states to act and the use of international law. In other words, the SRSG demanded exceptional measures for extreme situations. Depending on how much weight the interpreter puts on the Principle 7 title referring to 'conflict-affected areas' and the justificatory part in the Commentary referring to the 'incapacitated-by-conflict host state', one can discern two tracks of argumentation. If Principle 7 is about this narrow type of conflictrelated situations littered with gross abuses, then the exceptional measures the SRSG called for would be warranted only for such restricted circumstances (the 'special track'). If however the interpreter follows the analysis herein, which proposes that Principle 7 is about 'gross abuses' that require exceptional measures, whether in conflict situations of all sorts or in the absence of conflict altogether, then one can speak of a 'general track' requiring the same exceptional measures. It is against these two tracks that post-2011 developments - the reports of the UN Working Group of Experts and the National Action Plans - will be analysed in the next section. This analysis will shed light on how Principle 7 was understood and followed up by key stakeholders.

Both these 'special' and 'general' tracks reflect the SRSG's 'precision tool' view on international law. ${ }^{69}$ With respect to a treaty on corporate accountability, Ruggie's view contrasted with the preference of civil society groups and part of the legal academia arguing in favour of an overarching treaty on business and human rights. ${ }^{70}$ Through Principle 7 and the 2011 Recommendations, the SRSG displayed two instances - conflict zones and gross abuses - as candidates for international law action. Notably though neither of these two instances galvanized NGO advocacy ${ }^{71}$ and treaty-inclined academic proponents.

areas: state obligations and business responsibilities', Humanitarian debate: Law, policy, action - Business, violence and conflict, 94:887 International Review of the Red Cross (Autumn 2012).

68 European Parliament, Report on Corporate Social Responsibility: promoting society's interests and a route to sustainable and inclusive recovery (2012/2097(INI)), Rapporteur Richard Howitt (2013), para. K.

${ }^{69}$ In 2007 Ruggie began discussing ways to increase the effectiveness of the international human rights regime and referred to international legal instruments as 'precision tools'. He wrote: "International instruments may well have a significant role to play in this process, but as carefully crafted precision tools complementing and augmenting existing institutional capacities.” J. G. Ruggie, 'Business and Human Rights: The Evolving International Agenda', American Journal of International Law (2007).

${ }^{70}$ Ruggie explained his concern in a five-page public letter and emphasized that "[e]numerating these challenges is not an argument against treaties. But it is a cautionary note to avoid going down a road that would end in largely symbolic gestures, of little practical use to real people in real places, and with high potential for generating serious backlash against any form of further international legalization in this domain.” J. G. Ruggie, A UN Business and Human Rights Treaty?, Harvard Kennedy School Issues Brief, 28 January 2014.

${ }^{71}$ See however the call from a group of German NGOs urging the German government to "[a]ctively support all efforts to achieve an internationally binding standard for conflict-sensitive conduct in compliance with human rights”. Position Paper on Business and Human Rights - Expectations of a German Action Plan, CorA Network for Corporate Accountability and German Human Rights Forum, 2013. 
In contrast, the recent proposal for an overarching treaty that Ecuador put forward in 2013 ignited enthusiasm with some legal academics and NGOs, ${ }^{72}$ and gained the support of 85 states. It is conceivable that these two communities received coldly Principle 7, sensing that the highlighting that Principle 7 performs can easily move into reductionism, leaving some severe impacts not covered by Principle 7 out of the limelight. Similar concerns of reductionism would apply to the 2011 Recommendations putting forward gross abuses ${ }^{73}$ that would leave out of the discussion the lesser impacts of business activities, which would then be confined to the corporate 'voluntarism' realm of action. ${ }^{74}$

The express highlighting of the role of international law in Principle 7 failed to ignite the two communities and was quietly disregarded as a mere confirmation of the SRSG's general stance to side-line legal incentives in the evolution of the business and human rights regime. ${ }^{75}$ During the years, the SRSG received criticism for downplaying legal incentives and obligations. From the reluctance to call for an overarching treaty on business and human rights (charge of 'normicide') to the non-recognition of extraterritorial reach of state obligations to protect (charge of regressive interpretation of international human rights law) to the corporate 'responsibility' to respect unaccompanied by monitoring and enforcement mechanisms (charge of voluntarism bias), critics found fault with the SRSG and his "principled pragmatism” trademark approach for seemingly side-lining much needed law-making processes. ${ }^{76}$

The chilly response from NGOs and human rights academics regarding the legalization of the 'general track' showed that the 'general track' was not general enough as they preferred an overarching treaty establishing corporate and state accountability not only for gross abuses.

\footnotetext{
${ }^{72}$ Statement on behalf of a Group of Countries at the 24rd Session of the Human Rights Council, General Debate Item 3 “Transnational Corporations and Human Rights”, Geneva, September 2013. See also Ruggie, supra note 70; UN Working Group on Business and Human Rights statement at a workshop organised by the Permanent Mission of the Republic of Ecuador on "Human Rights and Transnational Corporations: Paving the way for a legally binding instrument”, 11 and 12 March 2014, Geneva.

${ }^{73}$ The European Parliament called on the Commission "to put forward proposals for better facilitating access to justice in EU courts for the most extreme, egregious cases of human or labour rights violations by European-based businesses or their subsidiaries, subcontractors or business partners, as recommended by the UN Secretary-General's Special Representative on Business and Human Rights”. European Parliament, Report on Corporate Social Responsibility: promoting society's interests and a route to sustainable and inclusive recovery (2012/2097(INI)), Rapporteur Richard Howitt (2013), para. 40 (italics added).

${ }^{74}$ "The focus and content of an international treaty is a matter for discussion. Some commentators have suggested the need to restrict its scope to the most egregious of human rights violations and I can see that there are good reasons, and a certain urgency, to address those violations. But I am less convinced that these issues should be the only ones to be dealt with in an international treaty." C. Lopez (ICJ), Workshop on Human Rights and Transnational Corporations - Paving the Way for a Legally Binding Instrument, Geneva, Palais des Nations, 11-12 March 2014. See also ESCR-Net, Oral Statement of ESCR-Net at the Side Event in Human Rights \& Business organized by the Permanent Missions of Ecuador and South Africa, 10 March, 2014; and Oral Statement of FIAN International at the Workshop on Human Rights and Business organized by the Permanent Mission of Ecuador and the South Center on 10 and 11 of March 2014.

${ }^{75}$ CETIM wrote that "regarding the Guiding Principles, the problem is not so much their content but rather that they are only guiding principles, and thus that they are not binding, not enforceable and provide for no sanctions. It would an illusion to hope that we will be able to discipline the most powerful actors in the global economy today with voluntary guidelines and soft laws. This is precisely why the TNCs support them.” CETIM, Europe - Third World Centre, oral Statement at the Workshop on Transnational Corporations and Human Rights, Geneva, 12 March 2014.

${ }^{76}$ P. P. Miretski and S.-D. Bachmann, 'The UN Norms on the Responsibility of Transnational Corporations and Other Business Enterprises with Regard to Human Rights: A Requiem’, 17 Deakin L. Rev. (2012) p. 5.
} 
Principle 7 brings to light the chasm between those seeing international law as a 'precision tool' and those aiming for comprehensive legalization as the best way to advance the business and human rights regime. In this way, Principle 7 appears as an illustration of a wider debate about the role of national and international law in this regime, about the controversies of how to advance rule-making in the current global context. ${ }^{77}$

In the next section the discussion turns to examining how Principle 7 was followed up within the UN, mainly by the Working Group on business and human rights, and within home states, especially by the adoption of National Action Plans for the implementation of the UNGPs. Attention goes to the relative priority given to conflict-affected zones as a distinct thematic area in the post-SRSG period, and to the traction that the SRSG's call for an international law process has received.

\section{The Follow Up to the SRSG Mandate}

Upon endorsing unanimously the UNGPs in 2011 the Human Rights Council set up a five-expert Working Group on business and human rights to which it entrusted a three-year mandate with multiple tasks such as awareness raising, identification of good practices and country visits. The Council also established an annual multistakeholder Forum on business and human rights. ${ }^{78}$ Furthermore, members states of the EU as well as some other non-EU states have pledged to follow up the UNGPs through National Action Plans (NAPs). ${ }^{79}$

\subsection{UN Working Group on Business and Human Rights}

The Working Group continued the broadly consultative and evidence-based approach that the SRSG employed and for which he is commended. This section documents how the issue of conflict-affected zones surfaced in the consultations and reports of the Working Group.

\subsubsection{Submissions to the Working Group in 2011}

At the beginning of its work the Working Group proceeded with a consultation asking states and stakeholders about opinions on two issues: what should be the priority areas for the work of the Working Group and what would be the means to ensure effective implementation of the Guiding Principles. The Working Group received views from over 50 respondents. ${ }^{80}$

\footnotetext{
77 B. Eberlein et al., 'Transnational business governance interactions: Conceptualization and framework for analysis', Regulation \& Governance (2013). See also the exchange between Human Rights Watch and John Ruggie: C. Albin-Lackey, Without Rules - A Failed Approach to Corporate Accountability, HRW, 2013, <www.hrw.org/world-report/2013/essays/112459> and J. Ruggie, Progress in Corporate Accountability, 4 February 2013, <www.ihrb.org/commentary/board/progress-in-corporate-accountability.html>.

78 Human Rights Council, Human rights and transnational corporations and other business enterprises, A/HRC/17/L.17/Rev.1, 2011, paras. 6 and 13.

${ }^{79}$ For a view to the process of drafting the NAPs in different states, see 'The diffusion of National Action Plans on business and human rights: An initial assessment', Journal of Human Rights Practice (forthcoming 2014).

${ }^{80}$ A full list of responses is available at <www.ohchr.org/EN/Issues/Business/Pages/Submissions.aspx >.
} 
The views communicated by states about priority areas emphasized conflict-affected zones only in a handful of cases: Russia mentioned a focus on vulnerable groups of people, especially "the rights of the child (including the rights of the child in an armed conflict) and the rights of people with disabilities”. France highlighted situations of denial of justice for victims, especially in areas of weak governance and conflict. Major economies however did not send their views: the US, China, Germany, Italy, Spain, and all BRICS except Russia are missing from the list of states that sent in comments about priority areas. The European Union referred in its submission to 'severity' of impacts and urged that the thematic UN procedures establish cooperation in order to clarify "how do they interpret 'severe' impacts [and] what action do thematic UN procedures require when 'severe' impacts are detected". ${ }^{81}$

Amnesty International in its submission proposed five key thematic areas among which two are related to conflict areas, although not mentioned as such. First, Amnesty impressed the need for home state regulation of corporate actors, "particularly with respect to operations conducted abroad", and thus states should legally require businesses to undertake human rights due diligence throughout their global operations "particularly where there is a high risk of human rights abuses arising". Second, Amnesty recalled that the SRSG acknowledged that "supplementary measures such as a multilateral legal instrument on business and human rights may be required to provide greater clarity and increase legal protections" and thus Amnesty called for the Working Group to "analyze the options for addressing weaknesses and gaps in the legal protection of human rights including, but not limited to, those related to gross human rights abuses, and it should make recommendations for action" ${ }^{82}$ Oxfam Australia urged the Working Group to consider some key issues among which was the human rights impact of large scale projects (in agri-business, mining, hydropower, logging and infrastructure) and conflict and corruption (and thus to link the UNGPs to emerging global tax justice and revenue transparency initiatives).

The submission from the Mining and Energy Committee on Security and Human Rights (Columbia) documents how this public-private partnership identifies, builds and disseminates best practices around security issues by using the Voluntary Principles on Security and Human Rights. Iveta Cherneva in her submission called for the Working Group not to lose sight of the private military industry.

\subsubsection{Surveys of States and Businesses by the Working Group in 2012}

In its effort to develop "an evidence-based foundation for informing the discussions among stakeholders on the implementation of the Guiding Principles”, the Working Group conducted in 2012 two surveys targeted at states and businesses. The 2013 report reports on the results. ${ }^{83}$ The state survey, based on 26 country responses, mentions that "[t]he challenges associated with

\footnotetext{
${ }^{81}$ See <www.ohchr.org/Documents/Issues/TransCorporations/Submissions/UNAndIGOs/EuropeanUnion.pdf> .

${ }^{82}$ Amnesty International, Submission to the Working Group, 8 December 2011, pp. 5 and 7 (italics added), $<$ www.ohchr.org/Documents/Issues/TransCorporations/Submissions/CivilSociety/AmnestyInternational.pdf $>$.

${ }^{83}$ The results are detailed in an addendum to the report called Uptake of the Guiding Principles on Business and Human Rights: practices and results from pilot surveys of Governments and corporations, A/HRC/23/32/Add.2, 16 April 2013 (hereinafter: Uptake of the Guiding Principles)
} 
business effects in contexts where there is violence, armed conflict, piracy or criminal activity were frequently mentioned by States as priority focus areas". ${ }^{84}$ Private Security Providers were mentioned by two of the responding states as industries of interest. ${ }^{85}$

Interestingly, as the Working Group inquired into examples of implementation of the UNGPs in general, states reported mostly actions related to conflict-affected zones. Thus, as an example of state action through "multi-stakeholder accountability" schemes, the International Code of Conduct for Private Security Providers is mentioned; actually this is the only item reported under the rubric. Further, under the rubric "State mandatory human rights due diligence and reporting”, all mandatory requirements that states mentioned are related to conflict-affected areas. Thus, a Peruvian regulatory initiative targets banks to prevent and address conflicts related to mining projects that banks support (the regulation promotes a "conflict-sensitive approach to lending"). Further, the US Dodd-Frank Act (section 1502) is mentioned, and it focuses on conflict minerals sourced from the Democratic Republic of Congo. Finally the US reporting regulations for US businesses investing in Myanmar require information about the security providers such investors use as well as the grievances mechanisms for local communities. ${ }^{86}$

The business survey, based on around 120 responses, wrote that when it comes to businesses addressing their impacts the "challenges included ... (c) a lack of understanding of company responsibilities in situations where government institutions are lacking”. ${ }^{87}$

\subsubsection{Feedback from the 2012 Multistakeholder Forum on Business and Human Rights}

Based on presentations and discussions at the Multistakeholder Forum, the Working Group identified a range of priorities. Regarding Pillar 1, a priority is " $[\mathrm{t}] \mathrm{o}$ explore with all stakeholders possible avenues to address the gap in situations of conflict and in the absence of effective State authority". ${ }^{8}$ Regarding access to remedies, the Working Group stressed the need "to further explore possible developments to address the lack of judicial remedies for gross human rights abuses". ${ }^{89}$ Furthermore, Section 8 of the Report refers to "Situations of conflict" which should be quoted in its entirety to get a clearer impression of how the Group approaches the issue of conflict areas:

The Working Group noted multiple national, intergovernmental, industry and multi-stakeholder initiatives to regulate and set both voluntary and mandatory standards for business investment and operations in situations of conflict. It also noted the potential role of investors, credit agencies, stock exchanges, national legislation with extraterritorial applications and regional mechanisms in supporting the enhanced implementation by business of the Guiding Principles, including human rights due diligence and operational grievance mechanisms. The Working Group identified as priorities the need:

(a) To assess the effectiveness of existing initiatives and guidelines in situations of conflict, including with regard to access to remedies, and the identification of gaps and lessons learned;

\footnotetext{
${ }^{84}$ Report of the Working Group on the issue of human rights and transnational corporations and other business enterprises, A/HRC/23/32 (2013), para. 24.

${ }^{85}$ Uptake of the Guiding Principles, supra note 83, para. 13.

${ }^{86}$ Ibid., paras. 43-48.

${ }^{87}$ Ibid., para. 36 (italics added).

${ }^{88}$ Report of the Working Group , supra note 84, para 43 b (italics added).

${ }^{89}$ Ibid., para. 47 d (italics added).
} 
(b) To support and strengthen existing initiatives based on lessons learned;

(c) To encourage greater coherence and alignment among relevant standards relating to situations of conflict and the Guiding Principles;

(d) To clarify guidance for business in situations of conflict;

(e) To collect evidence on the implementation of the corporate responsibility to respect in relation to transitional justice, reparations and post-conflict situations. ${ }^{90}$

\subsubsection{Reports of the UN Working Group (2012-2013)}

The Working Group has been issuing reports twice a year, one to the UN Human Rights Council in early spring and one to the UN General Assembly in late summer. The General Assembly reports are thematic: the first was about embedding the UNGPs into global governance frameworks, the second about indigenous peoples. ${ }^{91}$ Leaving these reports aside, there are two annual reports to date. In its first annual report, the Working Group outlined a number of strategic considerations guiding its three-year mandate. Here the Working Group put emphasis on implementing the UNGPs: "Implementation should remain focused on addressing the most severe forms of human rights impact of business activities, as well as the impact that impinges on the rights of persons living in vulnerable situations." 92 The second annual report of the Working Group refers to the complaints ('submissions') they received during 2012 alleging corporate abuses. From the approximately 40 submissions received:

an especially large number of cases involving conflicts between local communities and businesses over land and resources, including multiple reports of forced evictions as well as of businesses operating or having an impact on land traditionally used by, or of cultural significance to, indigenous peoples without their free, prior and informed consent. In many reports it was noted that conflicts between communities and businesses had led to the harassment and persecution of members of the communities affected, as well as of human rights defenders investigating, protesting, seeking accountability and access to remedies for victims of alleged abuses linked to business activities. This included instances of arbitrary detention, threats, violence and killings, targeting by armed groups, disappearances, restrictions of the freedoms of assembly and expression, and other violations of rights. ${ }^{93}$

\subsubsection{Report of the Office of the High Commissioner (2012)}

The OHCHR was asked by the Human Rights Council to report on how the United Nations system advances the business and human rights agenda, and on the dissemination and implementation of the UNGPs. This line of UN work is separate from the mandate of the Working Group, but it should be mentioned given that the UNGPs are a central reference point for a multitude of UN bodies examining the impacts of business on human rights. It also places Principle 7 in a wider UN perspective.

\footnotetext{
${ }^{90}$ Ibid., para. 51.

${ }^{91}$ Report of the Working Group on the issue of human rights and transnational corporations and other business enterprises, A/67/285 (2012) (regarding embedding into global governance frameworks); Report of the Working Group on the issue of human rights and transnational corporations and other business enterprises, A/68/279 (2013) (regarding indigenous peoples).

92 Report of the Working Group on the issue of human rights and transnational corporations and other business enterprises, A/HRC/20/29 (2012), para. 55 (italics added)

${ }^{93}$ Report of the Working Group , supra note 84, para. 13 (italics added).
} 
Regarding business activities in conflict-affected areas, the report notes the Security Council's activities regarding the conflict in the DRC, and in particular the due diligence guidelines for trade in mineral products issued by the Group of Experts supporting the Sanctions Committee. Further, the report writes that " $[\mathrm{t}]$ he Peacebuilding Support Office and the UNEP Post-Conflict and Disaster Management Branch provide policy guidance on the management of national resources and the role of the private sector". The report sees a direct correlation between the UN's peacebuilding strategies and the Guiding Principles to ensure "business activities support rather than undermine the building of sustainable peace” and calls for:

further exploration on policy questions on the linkages between business human rights and peacebuilding in the intergovernmental Peacebuilding Commission, and the Peacebuilding Fund (the multi-donor trust fund that provides a critical bridge between conflict and recovery), which is increasingly focused on natural resources management as a funding area in peacebuilding support. The Guiding Principles may also be relevant to the work of United Nations peacekeeping operations. ${ }^{94}$

\subsubsection{Assessment}

Compared with the high prominence the SRSG gave to conflict-affected areas, the Working Group's reports present a more subdued discussion of the topic, with thematic priorities apparently set elsewhere. What is precisely the position taken by the Working Group on the issue of conflict-affected zones? Is there seamless continuity with the conceptual approach of the SRSG (Principle 7) or can a change in framing the issue be detected?

The Working Group has referred repeatedly to conflict zones in its reports although clearly it did not make conflict-affected zones a thematic area as it was indigenous people and embedding the UNGPs in the UN system that were the chosen themes. Instead the Working Group indicated explicitly that severe abuses - in zones affected by conflict or not - are a priority when it comes to the implementation of the UNGPs. In addition to that, the Working Group selected access to remedies as one of its two priority projects, again remedies being needed for abuses taking place not only in conflict-affected zones. ${ }^{95}$ This follows closely the Human Rights Council resolution asking the Working Group "[t]o continue to explore options and make recommendations at the national, regional and international levels for enhancing access to effective remedies available to those whose human rights are affected by corporate activities, including those in conflict areas". 96

Furthermore, the Working Group's references to conflict are much broader than the justificatory part of Principle 7 Commentary would allow. From the Working Group's reports it is clear that it covers localized conflict around mines where the host state is clearly not incapacitated by conflict. Rather in such areas gross abuses of human rights take place, and often it is the

\footnotetext{
${ }^{94}$ Contribution of the United Nations system as a whole to the advancement of the business and human rights agenda and the dissemination and implementation of the Guiding Principles on Business and Human Rights, Report of the Secretary-General, A/HRC/21/21 (2012), para. 55.

${ }^{95}$ UN Working Group on Business and Human Rights statement at a workshop organised by the Permanent Mission of the Republic of Ecuador on "Human Rights and Transnational Corporations: Paving the way for a legally binding instrument”, 11-12 March <www.ohchr.org/Documents/Issues/Business/WGStatementEcuadorWorkshop12Mar2014.pdf>.

${ }^{96}$ Human Rights Council, supra note 78, para. 6(e) (italics added).
} 
governmental forces that perpetrate them. In this way, the Working Group followed the thrust of Principle 7's operational part which has always been focused on gross abuses and which could be applied to all zones of potential and localized conflict as they all generate higher risks of severe abuses. Rather than working on the stated assumptions behind Principle 7 - conflict areas where the government lost control over territory and is thus incapacitated in discharging its duty to protect, or conflicts where all parties disregard human rights and severe abuses ensue - the Working Group relaxed the notion of conflict-affected area and emphasized the severity of abuses. The Working Group indeed stated that efforts to implement the UNGPs have to prioritize addressing 'severe impacts'. This is an indication that the Working Group's approach to conflict developed along the 'general track' rather than the 'special track' outlined in Principle 7; they developed the 'gross abuse' theme (general track) in line with the operational part of Principle 7 and its Commentary while not feeling constrained by the justificatory part of Principle 7 Commentary.

The understanding from the Working Group seems to be that the 'general track' works well enough as long as 'severe' impacts and access to remedies are emphasized and prioritized by all stakeholders involved in implementing the UNGPs; in other words, as long as actions within all three pillars focus on severe impacts with priority. The way the post-SRSG debate in the UN seems to be shaping up is around 'severe' or 'gross' abuses requiring special measures, whether in conflict zones or not. In this debate, Principle 7 - with its uncertainties about the conflicts to which it applies - has become a subset of a broader discussion around gross violations.

Overall, between the SRSG mandate and the Working Group mandate, there is a discontinuity in the thematic framing of conflict-affected zones but continuity in the operational focus on gross abuses. Given the conflicted nature of Principle 7 displaying both the 'special' track and the 'general' track, the Working Group chose the latter. There is however another discontinuity: the SRSG's call for international law to be employed to deal with gross abuses and conflict zones. Thus the SRSG stood firm in his exceptional call for an international law instrument, while the Working Group did not manage to progress on, or give higher prominence to, the desirability to begin an international law-making process dedicated to conflict affected zones and gross abuses.

\subsection{National Action Plans}

The European Union firmly endorsed the UNGPs and committed to their implementation through diverse steps among which the National Action Plans (NAPs) occupy a central place. The 2011 Communication from the European Commission set a deadline providing that each member state adopt a plan for implementing the UNGPs by the end of 2012. The deadline was prolonged until the end 2013. Clearly the EU states have responded in a rather slow fashion. By April 2014, it is only the British, Danish and Dutch governments that have published a plan, with a number of other governments known to have undertaken multistakeholder consultations around plans. ${ }^{97}$ As

\footnotetext{
${ }^{97}$ Diffusion of National Action Plans, supra note 78.
} 
to the content of the upcoming plans, the preliminary benchmarks put forward by the European National Human Rights Institutions early in the process, in 2012, should be noted. ${ }^{98}$

The UK NAP touches directly on conflict-affected zones in different ways and areas. The government mentions the Building Stability Overseas Strategy to influence business activity in "conflict and fragile states, or countries with high levels of criminal violence"; the export of "strategic" goods and technology which is controlled by the government though the export licensing system (licences denied if there is "a clear risk that the proposed export might be used for internal repression"); support for the International Code of Conduct for Private Security Service Providers; support the Voluntary Principles on Security and Human Rights including through the UK Chairmanship in 2014; and a partnership with Columbia seeking to implement the UNGPs. ${ }^{99}$

The Dutch NAP does not refer to the theme of conflict-affected areas beyond noting the OECD work on conflict minerals. Instead the NAP highlights the issue of human rights abuses in the supply chains of Dutch companies. To address such risks of abuses, "the government wants to work on structural solutions within international chains, not incident management" and states that Sector Risk Analysis has been introduced "to identify the sectors that present the greatest risk of adverse social impacts" and that "[t]he government will enter into dialogue with the sectors identified in the analysis to explore how the situation can be improved". ${ }^{100}$ Without referring to 'gross', 'egregious', 'severe' impacts, the NAP refers to 'high-risk' sectors and projects that will receive priority attention from the government.

The Danish NAP emphasizes the importance of judicial remedies (criminal and civil) for dealing with "gross human rights violations". An inter-ministerial working group will discuss "the need for and feasibility of legislation with extraterritorial effect in areas of particular relevance [and] will examine the need for judicial prosecution of severe human rights impacts". ${ }^{101}$ There is however no specific reference to conflict affected zones in the entire NAP. Only the appendix refers to conflict zones, as it identifies for each principle of the UNGPs the governmental initiatives undertaken before and after the adoption of the UNGPs. From all the initiatives mentioned under Principle 7, only two refer specifically to conflict zones and in a rather general manner. ${ }^{102}$

The US Paper takes stock of the multitude of US activities and makes direct references to conflict zones. The Dodd-Frank Act's section 1502 mandates transparency on the due diligence in sourcing minerals from the DRC; related to this, in 2011 the launch of a US-led multistakeholder

\footnotetext{
${ }^{98}$ European Group of National Human Rights Institutions, Implementing the UN Guiding Principles on Business and Human Rights: Discussion paper on national implementation plans for EU Member States, 2012, <http://businesshumanrights.org/media/eu-nhris-paper-on-national-implementation-plans-for-ungps-210612-short.pdf> .

${ }^{99}$ Good Business - Implementing the UNGPs, UK Action Plan, 2013.

${ }^{100}$ Netherlands, National Action Plan on Business and Human Rights, December 2013

${ }^{101}$ Danish National Action Plan - Implementation of the UN Guiding Principles on Business and Human Rights, Danish Government, March 2014, p. 16.

${ }^{102}$ One indicates that "Danish development assistance generally contributes to the promotion of human rights in conflict areas. In conflict areas it is often difficult to work closely with the host country, because local authorities do not always have sufficient capacity to monitor and legislate. The Danish efforts in fragile states include support for building institutional framework." The other states that "[t]he Danish Government has provided financial assistance to the OECD Proactive Agenda work which has a specific focus on conflict-affected areas.” Ibid., p. 30.
} 
coalition ("Public Private Alliance for Responsible Minerals Trade") took place which is focused on promoting the sourcing of conflict-free minerals in the Great Lakes Region of Africa. The Paper also mentions the pivotal role played by the US in strengthening the Voluntary Principles on Security and Human Rights. Finally the Paper records the support for the International Code of Conduct for Private Security Service Providers concretized also into making membership a requirement for companies bidding ${ }^{103}$ for US government contracts. ${ }^{104}$

The analysis of the NAPs and US Paper issued until April 2014 reveal a mixed picture regarding the theme discussed herein. Some NAPs, from the UK and US, dealt expressly with the theme of conflict zones; this is explainable given that both of these countries have been involved with conflict-related CSR initiatives before the 2011 UNGPs and both states have large private military service company (PMSC) industries. Some other NAPs, from the Netherlands and Denmark, do not even mention conflict zones and instead frame the discussion in terms of gross abuses and remedies. Furthermore, even the US Paper and UK NAP do not refer to conflict in the circumscribed way that the justificatory part of Principle 7 would require; instead, these NAPs describe home state action targeting localized conflicts around extractive industry projects. The US Paper and UK NAP do display home states discharging their responsibility to act in conflictaffected areas, including by passing hard laws and supporting elaborate multistakeholder platforms (private regulation).

What is noticeably absent from NAPs is any reference supporting the call of the SRSG for an international law instrument dedicated to conflict-affected zones or to 'gross abuses' approaching international crimes. So while there is home state action on the national law front, on the international law front the NAPs offer no glimmer of progress towards an international treaty on either the special track (conflict) or general track (gross abuses).

\subsection{The 2014 EC Proposal on Conflict Minerals}

The US Dodd-Frank Act's section 1502 attracted worldwide attention as well as the call from the European Parliament for the EU to replicate the US model of transparency regulation of conflict minerals. ${ }^{105}$ The European Commission has recently issued its proposal which is deprived of a hard law component; invoked were the compliance choices of companies that simply redirected their supply chains away from DRC and the wider Great Lakes Region in response to the Dodd

\footnotetext{
${ }^{103}$ Percy explained why companies have been strong drivers of regulation and adopted "a surprisingly tough line on human rights": "From the beginning, both PMCs and PSCs have been enthusiastic advocates of regulation, participating in nearly all significant regulatory efforts. This enthusiasm is laudable, but it must not be regarded as selfless. Both PMCs and PSCs have sought states as their main clients and regulation suits them well. It provides legitimacy...” Percy, supra note 1.

${ }^{104}$ State Department to Incorporate International Code of Conduct into Worldwide Protective Services Contracts, Washington, DC, 16 August 2013, <http://www.state.gov/r/pa/prs/ps/2013/08/213212.htm>; U.S. Government Approach on Business and Human Rights, 1 May 2013, <http://www.humanrights.gov/wpcontent/uploads/2013/06/USG-Approach-on-Business-and-Human-Rights-updatedJune2013.pdf>.

${ }^{105}$ M. Narine, 'From Kansas To The Congo: Why Naming And Shaming Corporations Through The Dodd-Frank Act's Corporate Governance Disclosure Won’t Solve A Human Rights Crisis', 25 Regent University Law Review (2012-2013) p. 351.
} 
Frank Act's approach. ${ }^{106}$ Therefore the European Commission developed "an alternative but targeted and complementary model". ${ }^{107}$ It is a voluntary certification, opt-in system whereby EU companies (importers of raw materials) choose to certify themselves as responsible importers: "The onus will be put on the importers - a valuable point in the EU supply chain: The draft Regulation proposes to set up an EU system of self-certification for importers of tin, tantalum, tungsten and gold who choose to import responsibly into the European Union.”108

Leading NGOs received coldly the European Commission model and deemed "that the Commission's proposal - an opt-in self-certification scheme available to a limited number of companies - is likely to have minimal impact on the way that the majority of European companies source natural resources". ${ }^{109}$ The disappointment over the fact that the European Commission chose not to use hard law measures requiring due diligence and transparency was echoed in a letter that Ruggie addressed to the Commission. There he put forth that the voluntary reporting approach is problematic from the UNGPs perspective: under Principle 19, 'formal reporting' is expected from companies when 'severe impacts' are present, as in conflict situations. Ruggie's concern is that:

the legislative proposal before the Commission may view such reporting as merely optional. ... a move to make reporting entirely optional risks leaving the most responsible companies exposed while those least attentive to their human rights responsibilities continue their current practices undeterred. It is surely through requiring the same reporting standards across companies that the Commission can help drive improvements where they are most needed and advance corporate respect for human rights in practice. $^{110}$

Overall the European Commission's proposal can be seen as a setback for the approach put forward in the UNGPs. On the upside, the European Commission's proposal aligns with the SRSG's call for home states to act regarding conflict zones abroad and for an international instrument to be used. However, on the downside, the European Commission opted for a voluntary scheme instead of the hard law measures called for by the SRSG for conflict areas and gross abuses.

\section{Conclusions}

\footnotetext{
106 The NGO SOMO staunchly advocates for hard law solutions though mindful of designing them in a way that does not harm the intended beneficiaries. Thus regarding conflict minerals SOMO aims to "enhance the due diligence conducted by multinational corporations through binding regulations in a manner that makes the biggest contribution to lasting peace and improves livelihoods in conflict-affected and high-risk areas. In the case of conflict minerals from the DRC, it is recognised that such due diligence should be undertaken in a manner that does not contribute to the de facto embargo of minerals from the region.” Conflict Due Diligence by European Companies, SOMO, 2013, (italics added)

${ }^{107}$ European Commission, EU proposes responsible trading strategy for minerals from conflict zones, Press release, 5 March 2014.

${ }^{108}$ FAQs, <http://europa.eu/rapid/press-release_MEMO-14-157_en.htm>.

109 'Proposed EU law will not keep conflict resources out of Europe, campaigners warn', 5 March 2014, <www.globalwitness.org/library/proposed-eu-law-will-not-keep-conflict-resources-out-europe-campaigners-warn>.

110 J. G. Ruggie, Open letter Re: The EU Proposal on Conflict Minerals Due Diligence, Shift, 4 March 2014, $<$ http://business-humanrights.org/media/documents/ruggie-letter-barroso-eu-conflict-minerals-04-03-14.pdf>.
} 
Principle 7 which deals with 'conflict-affected zones' raises some uncertainties regarding its applicability to different types of conflict and gross abuses. The analysis herein concludes that the centre of gravity in Principle 7 is 'gross abuses' while 'conflict-affected areas' is one setting only, used for powerful exemplification. Contrary to its title Principle 7 is about (high risk of) gross abuses requiring exceptional actions from home states, and not narrowly about conflictaffected areas. Not only should 'conflict' in Principle 7 be interpreted broadly (to include localized conflicts and tensions generated by large business projects) but it should apply to nonconflict settings if gross abuses take place (to include repressive, authoritarian regimes). Appropriate home state action should follow 'gross abuses' in all of these settings. The title of Principle 7 could have benefited from the usual encompassing phrase - 'conflict-affected and high-risk areas' - used by the OECD and Global Compact to draw attention to business involvement in most serious abuses in weakly governed and repressive states.

An interpretation confined to highlighting potential ambiguities in the text of Principle 7 would however be incomplete and misleading if it did not account for the role of this Principle as a source for policy recommendations. The shortcomings exposed so far should not detract from the important message contained in Principle 7: gross abuses demand exceptional response from the home states, including in the form of an international law instrument. By amalgamating the issues of 'gross abuses' and 'conflict zones', Principle 7 taps two separate normative sources able to fuel a call for home states to act. The two sources have to do with recent developments in international criminal law displaying an "expanding web” of accountability (gross abuses) and with the systemic gap in the human rights regime when the host state is dysfunctional (conflictaffected zones). The policy thrust behind Principle 7 is to achieve the 'triad' of international humanitarian law, international criminal law and a Principle 7-based treaty to deal with gross abuses. Principle 7 attempted a sensitizing move by highlighting gross abuses in a special, most dramatic context: conflict zones with an incapacitated state.

The post-UNGPs developments (2011-2014) inform both the interpretation of Principle 7 and the limited traction the SRSG's call for new international law measures has achieved. If the drafting of Principle 7 was part of an effort to gather maximum normative force to push forward a rulemaking process at the international level, it has so far failed to deliver. All stakeholders seem to have disregarded the SRSG's call: some stakeholders (home states, the Working Group, the UN Human Rights Council) keep silent and remain inactive regarding international law measures, while some other stakeholders (developing countries lead by Ecuador, some NGOs and legal academics) disregarded the SRSG's call as reflecting a too narrow view on how international law should be used. Many in the human rights community have long been sceptics of the legalization proposed by the SRSG given his view of international law as 'precision tool'; rather than support the SRSG's call, which is deemed to be too narrow, some NGOs and legal academics embraced the 'overarching treaty' view of international law put forward by Ecuador and supported by 85 states.

The importance of a proper understanding of Principle 7 does not lie solely in its applicability to factual situations on the ground (UNGPs are not hard law). Rather the interpretation proposed herein aims for clarity in order to maintain the highly persuasive and communicative power of the UNGPs which would be diminished by divergent interpretations, and also accounts for how the drafting of Principle 7 sought to gain maximum normative force to get home states to act. As interpreted herein, Principle 7 is a foundational principle dealing with the responsibilities of 
home states to act forcefully (international and national law) when 'their' companies operating abroad are involved in gross abuses, and not merely an operational, context-specific principle limited to conflict-affected zones where the host states is incapacitated by conflict.

\section{Annex: Principle 7 of the UNGPs}

\section{Supporting business respect for human rights in conflict-affected areas}

7. Because the risk of gross human rights abuses is heightened in conflict-affected areas, States should help ensure that business enterprises operating in those contexts are not involved with such abuses, including by:

(a) Engaging at the earliest stage possible with business enterprises to help them identify, prevent and mitigate the human rights-related risks of their activities and business relationships;

(b) Providing adequate assistance to business enterprises to assess and address the heightened risks of abuses, paying special attention to both gender-based and sexual violence;

(c) Denying access to public support and services for a business enterprise that is involved with gross human rights abuses and refuses to cooperate in addressing the situation;

(d) Ensuring that their current policies, legislation, regulations and enforcement measures are effective in addressing the risk of business involvement in gross human rights abuses.

\section{Commentary}

Some of the worst human rights abuses involving business occur amid conflict over the control of territory, resources or a Government itself - where the human rights regime cannot be expected to function as intended. Responsible businesses increasingly seek guidance from States about how to avoid contributing to human rights harm in these difficult contexts. Innovative and practical approaches are needed. In particular, it is important to pay attention to the risk of sexual and gender-based violence, which is especially prevalent during times of conflict.

It is important for all States to address issues early before situations on the ground deteriorate. In conflict-affected areas, the "host" State may be unable to protect human rights adequately due to a lack of effective control. Where transnational corporations are involved, their "home" States therefore have roles to play in assisting both those corporations and host States to ensure that businesses are not involved with human rights abuse, while neighboring States can provide important additional support.

To achieve greater policy coherence and assist business enterprises adequately in such situations, home States should foster closer cooperation among their development assistance agencies, foreign and trade ministries, and export finance institutions in their capitals and within their embassies, as well as between these agencies and host Government actors; develop earlywarning indicators to alert Government agencies and business enterprises to problems; and attach appropriate consequences to any failure by enterprises to cooperate in these contexts, including by denying or withdrawing existing public support or services, or where that is not possible, denying their future provision. 
States should warn business enterprises of the heightened risk of being involved with gross abuses of human rights in conflict-affected areas. They should review whether their policies, legislation, regulations and enforcement measures effectively address this heightened risk, including through provisions for human rights due diligence by business. Where they identify gaps, States should take appropriate steps to address them. This may include exploring civil, administrative or criminal liability for enterprises domiciled or operating in their territory and/or jurisdiction that commit or contribute to gross human rights abuses. Moreover, States should consider multilateral approaches to prevent and address such acts, as well as support effective collective initiatives.

All these measures are in addition to States' obligations under international humanitarian law in situations of armed conflict, and under international criminal law. 